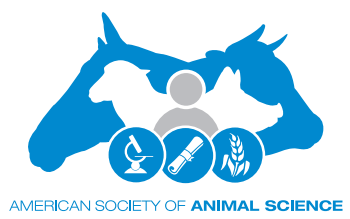

\title{
A combination of Lactobacillus buchneri and Pediococcus pentosaceus extended the aerobic stability of conventional and brown midrib mutants-corn hybrids ensiled at low dry matter concentrations by causing a major shift in their bacterial and fungal community
}

Juan J. Romero, ${ }^{\dagger, 1}$ Jin Park, ${ }^{\ddagger}$ Younghoo Joo, ${ }^{\ddagger}$ Yuchen Zhao," Marjorie Killerby, ${ }^{\dagger}$ Diana C. Reyes, ${ }^{\dagger}$ Francesco Tiezzi, ${ }^{\$}$ Eduardo Gutierrez-Rodriguez, ${ }^{\natural}$ and Miguel S. Castillo**

\begin{abstract}
${ }^{\dagger}$ Animal and Veterinary Sciences, School of Food and Agriculture, University of Maine, Orono, ME 04469, ${ }^{\ddagger}$ Department of Animal Science (BK21Plus, Institute of Agriculture and Life Science), Gyeongsang National University, Jinju, South Gyeongsang 52828, Republic of Korea, "Department of Animal Nutrition and Feed Science, China Agricultural University, Beijing, Beijing Municipality 100093, China, ${ }^{\$}$ Department of Animal Science, North Carolina State University, Raleigh, NC 27695, "Department of Horticulture and Landscape Architecture, Colorado State University, Fort Collins, CO 80523, ${ }^{* *}$ Department of Crop and Soil Sciences, North Carolina State University, Raleigh, NC 27695
\end{abstract}

${ }^{1}$ Corresponding author: juan.romero@maine.edu

ORCiD numbers: 0000-0002-2545-0003 (J. Romero); 0000-0002-3041-623X (Y. Joo); 0000-0002-9288-9577 (M. Killerby); 0000-0003-2433-0621 (D. Reyes); 0000-0002-4358-9236 (F. Tiezzi); 0000-0003-1066-5906 (M. Castillo).

\begin{abstract}
We evaluated the effects of applying a combination inoculant to four corn hybrids harvested at high moisture on their nutritive value and microbial populations. The treatment design was the factorial combination of corn hybrids ensiled with (INO) and without (CON) inoculant. The hybrids were TMF2R737 (MCN), F2F817 (MBR), P2089YHR (PCN), and PI144XR (PBR), ensiled at dry matter (DM) concentrations of 30.5\%, 26.3\%,31.1\%, and 31.5\%, respectively; MBR and PBR were brown midrib mutants (BMR). The inoculant contained Lactobacillus buchneri and Pediococcus pentosaceus $(4 \times$ $10^{5}$ and $1 \times 10^{5} \mathrm{cfu} / \mathrm{g}$ of fresh corn). The experiment had a complete randomized design with treatments replicated six times. Corn was treated or not with inoculant, packed into $7.6 \mathrm{~L}$ bucket silos, and stored for $100 \mathrm{~d}$. At $\mathrm{d} 0$, the relative abundance (RA, \%) of Enterobacteriaceae was lower in PBR vs. the other hybrids [51.3 vs. $\overline{\mathrm{x}}=$ (average of) 58.4] and in the case of fungi, incertae sedis (i.s.) Tremellales and Mucoraceae were more and less abundant, respectively, in conventional hybrids vs. BMRs ( $\overline{\mathrm{x}}=25.8$ vs. $\overline{\mathrm{x}}=13.9$ and $\overline{\mathrm{x}}=3.64$ vs. $\overline{\mathrm{x}}=7.52 ; \mathrm{P}<0.04$ ). After ensiling, INO had higher LAB (9.3 vs. $7.1 \log \mathrm{cfu} / \mathrm{g}$ of fresh corn) and acetic acid ( $3.44 \%$ vs. $1.32 \%$ of DM) and lower yeast (3.1 vs. 4.6$)$ and molds (1.5 vs. 3.0), and also extended the aerobic stability (582 vs. $111 \mathrm{~h}$ ) but decreased DM recovery $(95.6 \%$ vs. $97.4 \%)$ vs. CON $(P<0.02)$. Inoculation reduced bacterial phylogenetic diversity ( $6.75 \mathrm{vs}$. 14.4) but increased fungal observed taxonomical units (46 vs. 20$)$ vs. CON $(P<0.01)$. Also, a higher relative abundance (RA) for Lactobacillaceae $(99.2 \%$ vs. $75.7 \%)$ and lower for
\end{abstract}


Enterobacteriaceae (0.28 vs. 9.93) was observed due to inoculation $(P<0.001)$. For fungi, INO had a lower RA compared to CON for Monascaceae (12.6 vs. 44.7$)$ and increased i.s. Tremellales (8.0 vs. 1.2) and i.s. Saccharomycetales (6.4\% vs. $0.3 \% ; \mathrm{P}<0.006)$. Inoculation changed the diverse bacterial community found in the phyllosphere across hybrids to a taxonomically uneven one dominated by Lactobacillaceae. In the case of fungi, INO application increased the fungal diversity at $\mathrm{d} 100$ mainly by reducing the dominance of Monascaceae vs. CON. In conclusion, the INO treatment overwhelmed the disparate microbial populations found across BMR and conventional hybrids ensiled at low DM concentrations and ensured a significant concentration of acetic acid that modified fungal populations and in turn extended the aerobic stability of all hybrids.

Key words: 16 S and ITS sequencing, hybrid, inoculant, silage

\begin{tabular}{ll} 
Abbreviations & \\
\hline ADF & acid detergent fiber \\
ADV & additives \\
CP & crude protein \\
DM & dry matter \\
i.s. & incertae sedis \\
L:A & lactic to acetic acid ratio \\
LAB & lactic acid bacteria \\
NDF & neutral detergent fiber \\
NGS & next generation sequencing \\
OM & organic matter \\
OTU & observed taxonomical unit \\
RA & relative abundance \\
WSC & water soluble carbohydrates \\
\hline
\end{tabular}

\section{Introduction}

Consistency in silage nutrient preservation is a critical aspect of cattle feeding due to its effects on animal performance (Sniffen et al., 1993; Kertz, 1998; Gerlach et al., 2013), nutrient waste (Tylutki and Fox, 2000), and farm profitability (Rotz et al., 2003). A key source of variability in the preservation of nutrients during silage production is microbial spoilage resulting from less than ideal ensiling conditions (Borreani et al., 2018). Thus, mitigating spoilage processes is one of the most important strategies that can be implemented to preserve the nutritional value of conserved feeds and to prevent the significant dry matter (DM) losses that can occur during the storage and feed-out phases of ensiling (Borreani et al., 2018).

Addition of lactic acid bacteria (LAB) inoculants is an established strategy to mitigate silage nutrient losses (Pitt and Leibensperger, 1987; Muck et al., 2018). In the case of wholecrop corn, storage losses are less of a concern relative to feedout spoilage due to the high concentration of sugars and low buffering capacity which favors adequate acidification during ensiling (Martinez-Fernandez et al., 2013; Wilkinson and Davies, 2013). However, the acetic acid levels (an antifungal agent) can be often inadequate to ensure optimal aerobic stability of whole-crop corn silage during the feed-out phase (Filya et al., 2006; Basso et al., 2012; Wilkinson and Davies, 2013). To solve this issue, obligate heterofermentative LAB (e.g., Lactobacillus buchneri) inoculants were developed to increase the concentration of acetic acid in silages, but it can come at the expense of added DM losses (Blajman et al., 2018). Thus, combination inoculants were designed to include a facultative heterofermentative or homofermentative $\mathrm{LAB}$ with the purpose of suppressing spoilage microbes as early as possible during the fermentation phase by an extensive $\mathrm{pH}$ drop and in that way mitigate the undesirable secondary effects that can be observed with inoculants consisting solely of obligate heterofermentative LAB (Blajman et al., 2018; Muck et al., 2018). Even though the benefits of this approach have been reported in the literature, there are several reports where addition of combination inoculants had no positive effect without a clear explanation (Muck et al., 2018).

Due to climate change, the frequency of extreme weather events that can disrupt whole-crop corn harvest has increased in recent years (Rosenzweig et al., 2001; Kung et al., 2015; Wang et al., 2018) forcing producers in some instances to ensile wholecrop corn outside the recommended DM range (32\% to $35 \%$ ) that maximizes economic returns (Allen et al., 2003). Despite low DM $(<30 \%)$ silages being able to sustain higher fermentation rates, they also typically have higher populations of undesirable microbes such as clostridia and enterobacteria (Queiroz et al., 2018). At high moisture conditions, little is known about how combination inoculants affect the diverse bacterial and fungal communities found across corn hybrids with a diverse genetic background and how this in turn affects the ensiling process and its efficacy to preserve nutrients at both storage and feed-out phases. Our objectives were to assess the effect of a facultative and obligate heterofermentative LAB combination inoculant on the nutritional composition, fermentation profile, aerobic stability, and microbial communities of various corn hybrids ensiled at low DM concentrations. We hypothesized that combo inoculants extend aerobic stability and prevent nutrient losses to different extents across corn hybrids ensiled at low DM concentrations by a dissimilar modulation of spoilage microbial communities across hybrids.

\section{Materials and Methods}

\section{Experimental site, design, and treatments}

Field plots were located at the Mountain Research Station in Waynesville, NC $\left(35^{\circ} 29^{\prime} \mathrm{N} ; 8^{\circ} 58^{\prime} \mathrm{W}\right)$. Corn was planted in a clean-tilled seedbed on 3 June 2014 at a rate of 73,143 live seeds/ ha in $76-\mathrm{cm}$ row-widths. Based on initial soil test results, liquid $\mathrm{N}(32 \%)$ was applied at a rate of $515 \mathrm{~L} / \mathrm{ha}$ on 7 May 2014. Four corn hybrids (HYB) were used: TMF2R737 (MCN; Mycogen Seeds, Indianapolis, IN), P2089YHR (PCN; Pioneer Hi-Bred International, Jonhston, IA), F2F817 (MBR; Mycogen Seeds, Indianapolis, IN), and P1449XR (PBR; Pioneer Hi-Bred International, Jonhston, IA). Hybrids MBR and PBR were brown mid-rib mutants (BMR; loci 3 and 1 mutants, respectively). Corn plots were harvested on 1 October 2014 when DM concentration was $29 \%$ for all hybrids. Plot DM yields were 17.3, 23.9, 16.4, and 18.4 (mg/ha, $\pm 3.55 \mathrm{SD}$ ) for MCN, PCN, MBR, and PBR, respectively. Corn was clipped to $18-\mathrm{cm}$ stubble height and chopped to $1.9-\mathrm{cm}$ theoretical 
length using a John Deere 3955 forage harvester equipped with a kernel-processor (2.5 mm roll clearance, John Deere, Moline, IL). Two replicated piles (5.9 kg each, fresh weight basis) were obtained from each corn plot ( 6 per hybrid) for a total of 48 piles.

The two silage additives (ADV) evaluated were sterile doubledistilled water (CON) and inoculant (INO; Biotal Buchneri 500, Lallemand Animal Nutrition, Milwakee, WI). Each ADV treatment (CON or INO) were applied randomly to 1 of the 2 replicated piles at a rate of $1 \mathrm{~mL} / \mathrm{kg}$ of fresh corn. Inoculation resulted in theoretical final application rates of log $5.6 \mathrm{cfu} / \mathrm{g}$ of fresh corn (FW) for L. buchneri ATCC number 40,788 and log $5 \mathrm{cfu} / \mathrm{g}$ FW for Pedioccocus pentosaceus plus fibrolytic enzymes from Trichoderma reesei $(1,103,3,145$, and $50 \mathrm{mg}$ of sugar released $/ \mathrm{min} / \mathrm{g}$ for $\beta$-glucanase, xylanase, and galactomannanase activities, respectively; FCC, 2015). Chopped whole-crop corn (5.1 kg fresh basis) was packed into $7.6 \mathrm{~L}$ plastic buckets using an A-frame 12-ton hand-press and sealed with a rubber gasket lid and duct tape [ $*$ (average of) $202 \pm 15.4 \mathrm{~kg} \mathrm{DM} / \mathrm{m}^{3}$ ]. Silos were stored at $23^{\circ} \mathrm{C}\left( \pm 1^{\circ} \mathrm{C}\right)$ for $100 \mathrm{~d}$ and weights were recorded individually at $\mathrm{d}$ 0 and 100 to determine DM recovery (Arriola et al., 2011).

\section{Sampling procedure}

At $\mathrm{d} 0$ and 100, samples (250 g, fresh basis) were taken from each individual replicate to determine nutritive value, fermentation profile, and the bacterial and fungal population via standard plating techniques. At d 0, samples were obtained immediately after treatment application. Additional sample-subsets were collected at d 0 and 100 to determine the composition and structure of the bacterial and fungal communities using next generation sequencing (NGS; $100 \mathrm{~g}$, fresh basis) and also aerobic stability analysis at $\mathrm{d} 100(2.5 \mathrm{~kg}$, fresh basis) following the procedures described by Romero et al. (2018).

\section{Laboratory analysis}

Chemical, microbial counts, and aerobic stability analyses Samples from $\mathrm{d} 0$ and 100 were processed for DM determination by drying at $60^{\circ} \mathrm{C}$ for $48 \mathrm{~h}$ in a forced-air oven. Dried samples were ground to pass the 1-mm screen of a Wiley mill (A.H. Thomas, Philadelphia, PA). Water extracts were prepared by mixing $25 \mathrm{~g}$ of fresh or ensiled corn with $225 \mathrm{~mL}$ of $0.1 \%$ sterile peptone water in a 400C Stomacher blender for 3 min (Seward Ltd., Worthing, UK) and the solution was filtered through two layers of sterilized cheesecloth. All nutritional composition, fermentation profile, microbial counts, and aerobic stability analyses were conducted as outlined in Romero et al. (2018).

Microbial and DNA extraction

Samples (100 g, fresh basis) from d 0 and 100 were weighed into $15.2 \times 22.9 \mathrm{~cm}$ sterile $0.076-\mathrm{mm}$ filter bags (FILTRA-BAG, VWR Co., Radnor, PA) and processed as described in Romero et al. (2018) to obtain microbial pellets. Extraction of DNA was done using the PowerLyzer-PowerSoil DNA isolation kit (MO BIO Labs Inc., Carlsbad, CA) following the manufacturer recommended procedure. Resulting DNA was quantified and visualized as outlined in Romero et al. (2018). The concentration of DNA for each PCR reaction was standardized for all samples at $5 \mathrm{ng} / \mu \mathrm{L}$.

NGS

Extracted DNA from pellets was analyzed using the Illumina (San Diego, CA) MiSeq platform for pair-end reads and 500 sequencing cycles. Amplification of the V4 hypervariable region of the 16S rRNA was achieved using the primer pair F515
(5'-CACGGTCGKCGGCGCCATT-3') and R806 (5'-GGACTACHVGGG TWTCTAAT-3') and the Internal Transcribe Spacer (ITS-1) region of fungi BITS (5'-NNNNNNNNCTACCTGCGGARGGATCA-3') and B58S3 (5'-GAGATCCRTTGYTRAAAGTT-3') as described by Caporaso et al. (2011) and by Bokulich and Mills (2013). The PCR conditions for both the 16S rRNA and ITS-1 amplifications are delineated in Romero et al. (2018). Amplicons were mixed at roughly equivalent ratios based on electrophoretic band intensity and purified using GE Illustra MicroSpin S-200 HR columns (GE Healthcare Biosciences, Piscataway, NJ). Pooled samples were submitted to the University of California Davis Genome Center for library preparation using the Kappa pairedend kit, cluster generation and $250 \mathrm{bp}$ paired-end sequencing on the MiSeq platform.

\section{Sequencing analysis}

Raw Illumina fastq files were demultiplexed, quality filtered (Q30), and analyzed using QIIME 1.9.1 and the GreenGenes 13.8, UNITE fungal ITS reference database as outlined in Romero et al. (2018). All samples were rarefied to a depth of 16,000 and 5,000 sequences per sample for 16S rRNA and ITS-1 libraries, respectively, before downstream analysis. The $\beta$-diversity (between-samples community dissimilarity) was calculated in QIIME using the weighted UniFrac distances for $16 \mathrm{~S}$ and the Bray-Curtis distances for ITS-1 (Lozupone and Knight, 2005). The $\alpha$-diversity was also estimated from rarefied observed taxonomical units (OTU) tables (Lozupone and Knight, 2005; Cole et al., 2009; Caporaso et al., 2011).

\section{Statistical analyses}

Data were analyzed separately for $\mathrm{d} 0$ and 100 . The experimental design was a completely randomized design replicated six times. The model was:

$$
\mathrm{Y}_{\mathrm{ijk}}=\mu+\mathrm{T}_{\mathrm{i}}+\mathrm{C}_{\mathrm{j}}+\mathrm{TC}_{\mathrm{ij}}+\mathrm{E}_{\mathrm{ijk}}
$$

where $Y_{i j k}$ is the response from the kth experimental unit receiving the ith level of corn hybrid and the jth level of ADV, $\mu$ is the general mean, $T_{i}$ is the effect of hybrid $i, C_{j}$ is the effect of $A D V j, T_{i j}$ is the effect of the hybrid $i \times A D V j$ interaction, and $E_{i j k}$ is the experimental error.

We used the GLM procedure of SAS v.9.4 (SAS Institute, 2019) for data analysis. When a two-factor interaction effect was present, we used the SLICE option to analyze the simple effects. Microbial data were converted to $\log 10$ to conduct statistical analysis and are presented on a fresh basis. Shapiro-Wilk test revealed that data were normally distributed. Mean separation was based on the PDIFF procedure of LSMEANS. Treatments were considered different when $P \leq 0.05$.

Further analysis was conducted to understand the overall relationships among the microbiota profile and silage quality variables and microbiota RA were adjusted by the effect of corn hybrid using a linear model. Residuals were considered as adjusted measures and were used in the association analysis. To account for the nonlinearity of the relationship between silage quality and microbiota RA, each bacterial and fungal family RA was classified into three categories: low, medium, and high RA. Categories were allocated based on the 34th and 67th percentiles of the specific family RA. A linear model was used to test the effect of family RA categories on silage quality variables, and pairwise contrasts between the three categories were used to identify trends in the change of silage quality variables as a function of family RA. This analysis was performed in $\mathrm{R}$ utilizing 
the packages "car" (Fox and Weisberg, 2018) and "lsmeans" (Lenth, 2016), which uses Tukey adjustment for multiple testing.

\section{Results and Discussion}

\section{Before ensiling $(0 \mathrm{~d})$}

Nutritional composition

All chemical composition response variables were affected by corn hybrid $(P<0.001)$ but not by ADV $(P>0.18$, Table 1$)$ right after inoculation. Among all hybrids, MBR had the lowest DM concentration (26.3) and it was also the least mature (early dent) compared to the other hybrids for which DM concentration ranged from $30.5-31.5( \pm 0.43 \%)$ and were at $1 / 4$ milk line at harvest time. Hybrid MBR had the lowest organic matter $(\mathrm{OM})$ concentration (95.5 vs. $96.4-96.8 \pm 0.08 \%$ of DM; $P<0.001)$ and the highest crude protein (CP; 9.63 vs. $7.79-8.33 \pm 0.146 \%$ of $\mathrm{DM} ; \mathrm{P}<0.001), \mathrm{NH}_{3}-\mathrm{N}$ (0.069 vs. $0.054-$ $0.058 \pm 0.0021 \%$ of $\mathrm{DM} ; \mathrm{P}<0.001)$, and neutral detergent fiber (NDF; 47.8 vs. $\overline{\mathrm{x}}=44.0 \pm 0.88 \%$ of $\mathrm{DM} ; \mathrm{P}<0.001$ ) when compared to the other hybrids, respectively. The water soluble carbohydrate (WSC) concentration was lower in MBR and PCN $(\overline{\mathrm{x}}=4.22)$ than in MCN and PBR $(\overline{\mathrm{x}}=5.63 \pm 0.324 \%$ of $\mathrm{DM}$, respectively; $P \leq 0.01)$. Similar maturity effects at $d 0$ on NDF and CP concentrations have been reported by other studies (Darby and Lauer, 2002; Lewis et al., 2004). Arriola et al. (2012) observed higher CP, NDF, and acid detergent fiber (ADF) and lower OM concentrations across four corn hybrids at $\overline{\mathrm{x}}=$ 25.3 vs. $\bar{x}=31.9 \%$ DM. Similarly, Windle et al. (2014) observed higher CP and lower WSC concentrations at $30.1 \%$ vs. $39.6 \%$ DM. In a previous study we conducted, Romero et al., (2018) evaluating the same hybrids treated or not with the same INO but ensiled at a higher DM, we also found that MBR had a much lower DM relative to the other hybrids at $\mathrm{d} 0(38.1 \%$ vs. $41.3 \%-44.0 \%$, respectively). Likewise, we also observed that MBR had the highest $\mathrm{CP}(6.85$ vs. $5.46-5.98)$ and $\mathrm{NH}_{3}-\mathrm{N}$ concentrations $(0.037 \%$ vs. $0.030 \%-0.032 \%$ of DM), but NDF was only higher when compared against PCN and PBR (44.7 vs. $\overline{\mathrm{x}}=42.1$ ) and similar to MCN (45.5\% of DM, respectively). Conversely, WSC was higher in MBR vs. all the other hybrids (5.49 vs. $\overline{\mathrm{x}}=3.49 \%$ of DM, respectively; Romero et al., 2018).

Phyllosphere microbial populations

The initial microbial population counts were affected by corn hybrid $(P<0.001)$ but not by ADV $(P>0.13$, Table 1$)$. A lower LAB population was observed for MBR and MCN $(\overline{\mathrm{x}}=7.69)$ compared to PCN and PBR $(\overline{\mathrm{x}}=8.39 \pm 0.228 \mathrm{log} \mathrm{cfu} / \mathrm{g}$ of FW, $\mathrm{P}<0.05)$. Hybrid PCN had a higher yeast population (6.79 vs. $\overline{\mathrm{x}}=6.0 \pm 0.139 \mathrm{log}$ $\mathrm{cfu} / \mathrm{g}$ of FW; $\mathrm{P}<0.001)$ and PBR a lower mold population (4.60 vs. $\overline{\mathrm{x}}=5.15 \pm 0.147 \mathrm{l} \log \mathrm{cfu} / \mathrm{g}$ of FW) compared to the others $(P<0.001)$. Comino et al. (2014) observed no effect of increasing DM from $27.6 \%$ to $32.5 \%$ on LAB $(\bar{x}=6.51)$, yeast $(\bar{x}=6.36)$, and mold ( $\overline{\mathrm{x}}=6.05$; log cfu/g of FW) counts at d 0 in whole-crop corn, respectively, which may indicate that at least within the DM range evaluated in this study maturity effects may not explain the differences in microbial counts. At a higher DM range (38.1\% to $44 \%$ ), Romero et al. (2018) reported that MBR and PBR $(\overline{\mathrm{x}}=7.69)$ had a higher LAB count than MCN and PCN $(\overline{\mathrm{x}}=6.90$ $\log \mathrm{cfu} / \mathrm{g}$ of FW) and no hybrid effects were observed on yeast and mold counts at $d 0(\bar{x}=6.67$ and $\bar{x}=5.87 \log \mathrm{cfu} / \mathrm{g}$ of FW, respectively). The current study had comparable yeast and mold counts relative to Romero et al. (2018) but a higher epiphytic LAB count, which may be partly due to the differences in DM, harvest month, and location. Windle et al. (2014) reported no differences in LAB $(\overline{\mathrm{x}}=5.97)$ and yeast $(\overline{\mathrm{x}}=5.33 \mathrm{log} \mathrm{cfu} / \mathrm{g}$ of FW) counts at d 0 in whole-crop corn ensiled at $31 \%$ or $40 \%$ DM. Conversely, Comino et al. (2014) reported lower LAB (6.44 vs. 7.29), yeast (6.33 vs. 6.80), and mold (6.01 vs. $7.03 \mathrm{log} \mathrm{cfu} / \mathrm{g}$ of FW) counts between $27.6 \%$ and $43.9 \%$ DM at $d 0$, respectively.

All rarefaction curves approached the saturation plateau, indicating that the coverage of bacterial (Supplemental Figure S1) and fungal (Supplemental Figure S2) diversity was sufficient to evaluate the bacterial and fungal community composition of whole-crop corn. At a sequencing depth of 16,000 and 5,000 sequences per sample for bacteria and fungi, respectively, we did not find an INO effect on bacterial and fungal observed OTUs $(P>$

Table 1. Chemical composition and microbial counts of chopped whole corn as a function of hybrid type (HYB) and bacterial inoculation (ADV) at $\mathrm{d}^{1}$

\begin{tabular}{|c|c|c|c|c|c|c|c|c|}
\hline \multirow[b]{2}{*}{ Item } & \multicolumn{4}{|c|}{ Hybrid } & \multirow[b]{2}{*}{ SEM } & \multicolumn{3}{|c|}{$P$-value } \\
\hline & MCN & PCN & MBR & PBR & & HYB & ADV & $\mathrm{HYB} \times \mathrm{ADV}$ \\
\hline $\mathrm{DM}, \%$ & $30.5^{b}$ & $31.1^{\mathrm{ab}}$ & $26.3^{c}$ & $31.5^{\mathrm{a}}$ & 0.43 & $<0.001$ & 0.585 & 0.598 \\
\hline $\mathrm{OM}, \%$ of $\mathrm{DM}$ & $96.8^{\mathrm{a}}$ & $96.7^{\mathrm{a}}$ & $95.5^{c}$ & $96.4^{\mathrm{b}}$ & 0.08 & $<0.001$ & 0.910 & 0.485 \\
\hline $\mathrm{CP}, \%$ of $\mathrm{DM}$ & $7.79^{c}$ & $8.33^{b}$ & $9.63^{a}$ & $7.96^{c}$ & 0.146 & $<0.001$ & 0.256 & 0.765 \\
\hline $\mathrm{NH}_{3}-\mathrm{N}, \%$ of $\mathrm{DM}^{2}$ & $0.054^{c}$ & $0.054^{c}$ & $0.069^{a}$ & $0.058^{b}$ & 0.0021 & $<0.001$ & 0.539 & 0.063 \\
\hline $\mathrm{NDF}, \%$ of DM & $44.2^{\mathrm{b}}$ & $43.6^{\mathrm{b}}$ & $47.8^{\mathrm{a}}$ & $44.2^{\mathrm{b}}$ & 0.88 & $<0.001$ & 0.183 & 0.707 \\
\hline $\mathrm{ADF}, \%$ of $\mathrm{DM}$ & $24.0^{\mathrm{a}}$ & $22.9^{\mathrm{b}}$ & $24.7^{\mathrm{a}}$ & $22.8^{\mathrm{b}}$ & 0.49 & $<0.001$ & 0.208 & 0.664 \\
\hline WSC, $\%$ of $\mathrm{DM}^{3}$ & $5.35^{\mathrm{a}}$ & $4.50^{\mathrm{b}}$ & $3.94^{\mathrm{b}}$ & $5.90^{\mathrm{a}}$ & 0.324 & $<0.001$ & 0.212 & 0.425 \\
\hline $\mathrm{pH}$ & $5.63^{b}$ & $5.59^{b}$ & $5.91^{\mathrm{a}}$ & $5.89^{a}$ & 0.083 & $<0.001$ & 0.972 & 0.432 \\
\hline Lactic acid bacteria, log cfu/g FW ${ }^{4}$ & $7.48^{\mathrm{b}}$ & $8.45^{\mathrm{a}}$ & $7.89^{\mathrm{b}}$ & $8.33^{\mathrm{a}}$ & 0.228 & $<0.001$ & 0.767 & 0.661 \\
\hline Yeast, log cfu/g FW & $6.08^{\mathrm{b}}$ & $6.79^{a}$ & $5.98^{b}$ & $5.94^{\mathrm{b}}$ & 0.139 & $<0.001$ & 0.125 & 0.352 \\
\hline Molds, log cfu/g FW & $5.14^{\mathrm{a}}$ & $5.20^{\mathrm{a}}$ & $5.10^{\mathrm{a}}$ & $4.60^{\mathrm{b}}$ & 0.147 & $<0.001$ & 0.180 & 0.302 \\
\hline
\end{tabular}

${ }^{1} \mathrm{MCN}, \mathrm{PCN}, \mathrm{MBR}$, and PBR corn hybrids are TMF2R737, P2089YHR, F2F817, and P1449XR, respectively. Hybrids MCN and MBR are property of Mycogen Seeds (Indianapolis, IN) and hybrids PCN and PBR are property of Pioneer Hi-Bred International (Johnston, IA). MBR and PBR are brown midrib hybrids. Additives were control (water) and inoculant (Biotal Buchneri 500; Lallemand Animal Nutrition, Milwakee, WI) delivering L. buchneri 40788 and P. pentosaceus at 400,000 and 100,000 cfu/g of fresh corn, respectively.

${ }^{2} \mathrm{NH}_{3}-\mathrm{N}$, ammonia-N.

${ }^{3}$ WSC, water soluble carbohydrates.

${ }^{4} \mathrm{FW}$, fresh corn.

${ }^{a-c}$ Means with different superscripts within a row are significantly different $(P \leq 0.05)$. 
$0.20)$, Heip's evenness index $(P>0.12)$ and bacterial phylogenetic diversity $(P=0.16)$. Bacterial OTUs and phylogenetic diversity were lower $(P<0.001)$ for MCN vs. the other hybrids (500 vs. $\bar{x}=$ 600 and 24.0 vs. $\overline{\mathrm{x}}=27.6$, respectively), and for PCN vs. PBR (563 vs. $640 \pm 21.3$ and 26.2 vs. $28.8 \pm 0.80$, respectively). Fungal OTUs were higher for PBR vs. the other hybrids (82.1 vs. $\overline{\mathrm{x}}=73.0)$ and for MBR vs. PCN (75.3 vs. $71.3 \pm 1.29 ; P<0.001)$. Also, Heip's evenness index indicates a more even fungal community in PBR vs. other hybrids (0.125 vs. $\overline{\mathrm{x}}=0.096)$ and in PCN vs. MCN (0.103 vs. $0.086 \pm$ $0.005, P<0.001)$. These results suggest that bacterial and fungal diversity may be higher for BMR compared to conventional hybrids tested in study at $\mathrm{d} 0$, as it was also reported by Romero et al. (2018) for the same hybrids. The implications of these differences may be related to some of the differences in pest resistance between BMR and conventional hybrids (Dowd et al., 2016), further research needs to confirm these observations. The weighted UniFrac (Figure 1) and Bray-Curtis (Figure 2) principal coordinates analysis plots indicated a separation and difference in the structure of the bacterial $(P=0.001)$ and fungal $(P=0.001)$ communities between hybrids at $\mathrm{d} 0$ but no difference between ADV $(P=0.588)$ according to the analysis of similarities test of distance metrics. Similar responses at $d 0$ were reported by Romero et al. (2018), as expected from samples collected right after ADV application.

The most abundant bacterial families observed at $d 0$ were Enterobacteriaceae, Pseudomonadaceae, Leuconostocaceae, and Xanthomonadaceae $(\overline{\mathrm{x}}=56.7 \%, 9.79 \%, 5.52 \%$, and $5.32 \% \mathrm{RA}$, respectively). The remaining families found had less than $5 \%$ RA. No ADV effects were observed on the relative abundance of bacterial families $(P>0.05)$ at d 0 except for Enterobacteriaceae $(P=0.03$; Table 2$)$ which had a lower RA for INO than CON $(54.8$ vs. $58.5 \pm 1.83 \%$ ). It is unclear how INO could have reduced the abundance of Enterobacteriaceae on d 0 but other studies have reported bacterial inoculant effects on bacterial and fungal populations at d 0 (Queiroz et al., 2013). Corn hybrid effects were observed for Enterobacteriaceae, Sphingobacteriaceae, Aeromonadaceae, Moraxellaceae, and Streptococcaceae $(P \leq 0.05)$. Enterobacteriaceae were least abundant in PBR (51.3) compared to the rest of the hybrids $(\overline{\mathrm{x}}=58.4 \pm 1.83 \%$; $\mathrm{P} \leq 0.01)$, while Sphingobacteriaceae were higher in PCN vs. MCN and MBR (5.25 vs. $\overline{\mathrm{x}}=3.26 \pm 0.47 \% ; P<0.001$ ), and Aeromonadaceae were higher in $\mathrm{MCN}$ than other hybrids (4.79 vs. $\overline{\mathrm{x}}=3.57 \pm 0.32 \% ; P<0.05$ ). Romero et al. (2018) also described Enterobacteriaceae as the dominant $(61.4 \%)$ bacterial family in low-moisture wholecrop fresh corn, followed by Sphingobacteriaceae (6.1\%), but with no hybrid or ADV effects. Similarly, high abundance of Enterobacteriaceae, Methylobactericeae, and Sphingomonadaceae was also identified by Ni et al. (2017) in whole-crop corn by NGS, while Drouin et al. (2019) described that Enterobacteriaceae and Pseudomonaceae were the most abundant bacterial families in the silk and tassel of fresh corn and Sphingobacteriaceae was mostly found in leaves and tassels. On many instances, beef or dairy pastureland or land and water in close proximity to animal operations presents significant higher populations of Enterobacteriaceae and Pseudomonaceae than land and water with little animal pressure (Wilde et al., 2000; Freitas et al., 2003). The most abundant genera were unidentified, Hafnia and Erwinia for Enterobacteriaceae, Pseudomonas and unidentified for Pseudomonadaceae, and Sphingobacterium for Sphingobacteriaceae. The genus Hafnia has been reported in Italian ryegrass silage (Heron et al., 1993), but few studies describe it as part of the phyllosphere microbiome of fresh corn. Some Hafnia species are known to be gut pathogens (Yin et al., 2019). Romero et al. (2018) and Ni et al. (2017) also

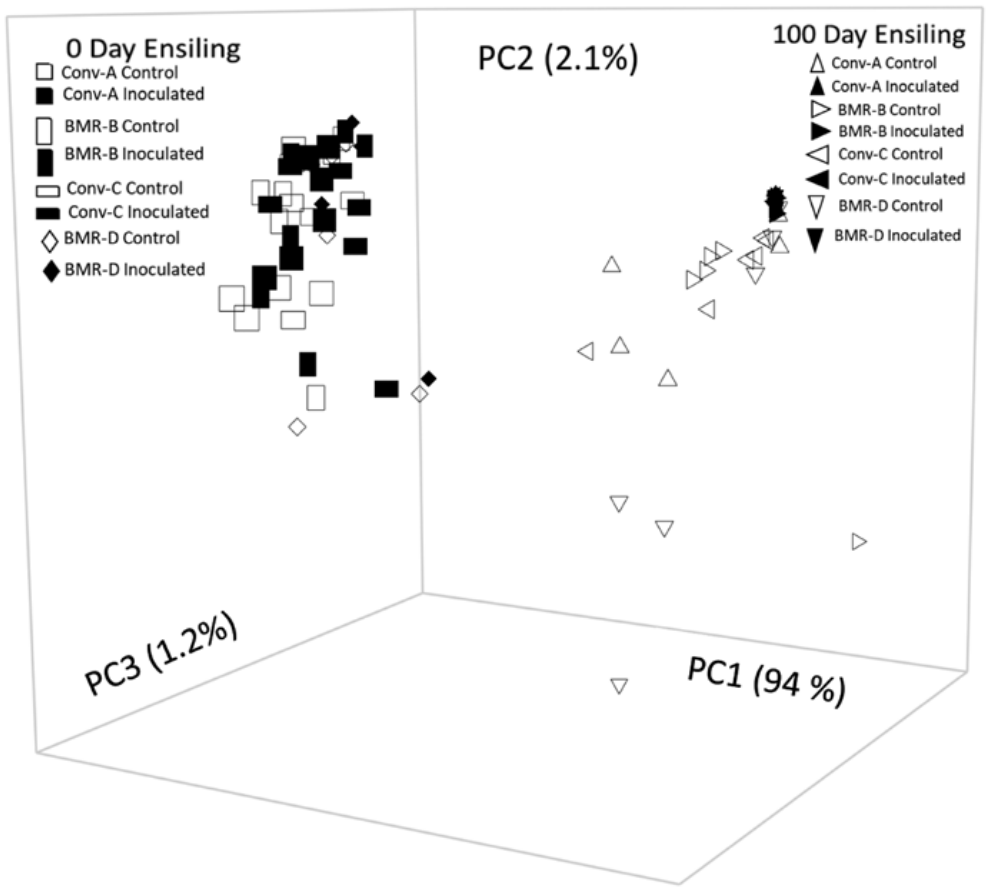

Figure 1. Weighted UniFrac principle coordinate (PC) analysis plots for bacterial OTUs coming from fresh (0 d) and ensiled (100 d) chopped whole-crop corn as a function of hybrid and bacterial inoculation. CON, control (water); INO, Inoculant. MCN, PCN, MBR, and PBR corn hybrids are TMF2R737, P2089YHR, F2F817, and P1449XR, respectively. Hybrids MCN and MBR are property of Mycogen Seeds (Indianapolis, IN) and PCN and PBR of Pioneer Hi-Bred International (Johnston, IA). MBR and PBR are brown midrib hybrids. Inoculant used was Biotal Buchneri 500 (Lallemand Animal Nutrition, Milwakee, WI) delivering L. buchneri 40788 and P. pentosaceus at 400,000 and $100,000 \mathrm{cfu} / \mathrm{g}$ of fresh whole-crop corn, respectively. 


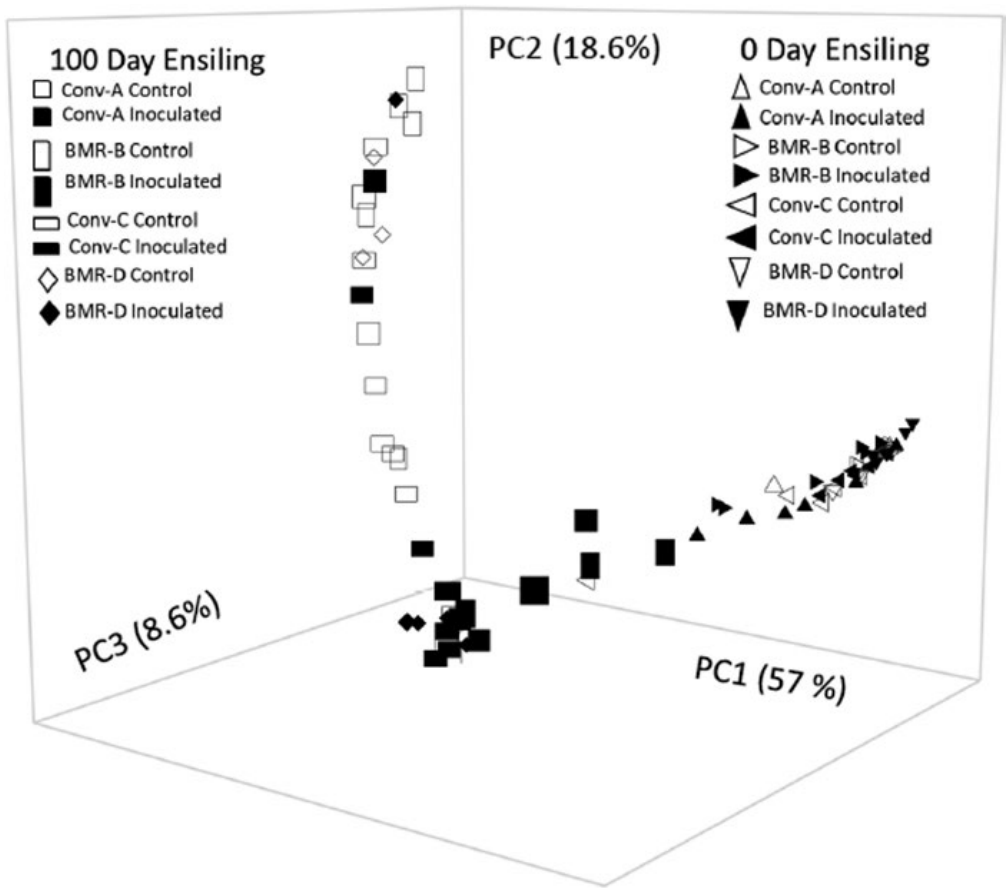

Figure 2. Bray-Curtis principle coordinate analysis plots for fungal OTUs coming from fresh $(0 \mathrm{~d})$ and ensiled (100 d) chopped whole-crop corn as a function of hybrid and bacterial inoculation. CON, control (water); INO, inoculant. MCN, PCN, MBR, and PBR corn hybrids are TMF2R737, P2089YHR, F2F817, and P1449XR, respectively. Hybrids MCN and MBR are property of Mycogen Seeds (Indianapolis, IN) and PCN and PBR of Pioneer Hi-Bred International (Johnston, IA). MBR and PBR are brown midrib hybrids. Inoculant used was Biotal Buchneri 500 (Lallemand Animal Nutrition, Milwakee, WI) delivering L. buchneri 40788 and P. pentosaceus at 400,000 and 100,000 $\mathrm{cfu} / \mathrm{g}$ of fresh whole-crop corn, respectively.

Table 2. Relative abundance (\%) of bacterial families identified from $16 \mathrm{~S}$ ribosomal DNA sequences extracted from chopped whole-crop corn as a function of hybrid (HYB) and silage additive (ADV) at $\mathrm{d} 0^{1}$

\begin{tabular}{|c|c|c|c|c|c|c|c|c|c|}
\hline \multirow[b]{2}{*}{ Item } & \multicolumn{4}{|c|}{ Hybrid } & \multirow[b]{2}{*}{ Mean } & \multirow[b]{2}{*}{ SEM } & \multicolumn{3}{|c|}{ P-value } \\
\hline & $\mathrm{MCN}$ & PCN & MBR & PBR & & & HYB & ADV & $\mathrm{HYB} \times \mathrm{ADV}$ \\
\hline Enterobacteriaceae & & & & & & 1.83 & 0.014 & 0.034 & 0.766 \\
\hline $\mathrm{CON}$ & - & - & - & - & $58.5^{\mathrm{A}}$ & & & & \\
\hline INO & - & - & - & - & $54.8^{\mathrm{B}}$ & & & & \\
\hline Mean & $58.9^{\mathrm{a}}$ & $57.8^{\mathrm{a}}$ & $58.5^{\mathrm{a}}$ & $51.3^{\mathrm{b}}$ & & & & & \\
\hline Pseudomonadaceae & - & - & - & - & 9.79 & 1.25 & 0.053 & 0.490 & 0.441 \\
\hline Leuconostocaceae & - & - & - & - & 5.52 & 2.04 & 0.700 & 0.691 & 0.660 \\
\hline Xanthomonadaceae & - & - & - & - & 5.32 & 0.80 & 0.151 & 0.243 & 0.475 \\
\hline Sphingobacteriaceae & $3.29^{b}$ & $5.25^{\mathrm{a}}$ & $3.22^{\mathrm{b}}$ & $4.44^{\mathrm{ab}}$ & & 0.52 & 0.009 & 0.087 & 0.347 \\
\hline Aeromonadaceae & $4.79^{a}$ & $3.42^{b}$ & $3.82^{b}$ & $3.57^{b}$ & & 0.35 & 0.018 & 0.866 & 0.560 \\
\hline Moraxellaceae & $1.88^{\mathrm{ab}}$ & $1.35^{\mathrm{b}}$ & $2.69^{a}$ & $2.01^{\mathrm{ab}}$ & & 0.25 & 0.014 & 0.253 & 0.663 \\
\hline Streptococcaceae & $1.85^{\mathrm{a}}$ & $1.09^{b}$ & $0.53^{c}$ & $0.79^{\mathrm{bc}}$ & & 0.23 & $<0.001$ & 0.873 & 0.691 \\
\hline
\end{tabular}

${ }^{1}$ MCN, PCN, MBR, and PBR corn hybrids are TMF2R737, P2089YHR, F2F817, and P1449XR, respectively. Hybrids MCN and MBR are property of Mycogen Seeds (Indianapolis, IN) and hybrids PCN and PBR are property of Pioneer Hi-Bred International (Johnston, IA). MBR and PBR are brown midrib hybrids. CON, control (water); INO, inoculant (Biotal Buchneri 500; Lallemand Animal Nutrition, Milwaukee, WI) delivering L. buchneri 40788 and P. pentosaceus at 400,000 and 100,000 cfu/g of fresh corn, respectively.

$A, B$ Means with different uppercase superscripts within a column are significantly different $(P \leq 0.05)$.

${ }^{a-c}$ Means with different superscripts within a row are significantly different $(P \leq 0.05)$.

reported Erwinia and Sphingobacterium in fresh whole-crop corn, but other studies differ in the main genera identified, including Acinetobacter, Klebsiella, and Weissella (Keshri et al., 2018) and Agrobacterium, Microbacterium, and Sphingobacterium (Xu et al., 2019).

Identification of fungi through ITS-detected sequences at d 0 yielded 240 OTUs belonging predominantly to the phyla Ascomycota (28.4\%), Basidiomycota (21.5\%), and Zygomycota (5.53\%), while $44.6 \%$ of the sequences belonged to unidentified fungi.
No ADV effects were observed for the major fungal families ( $P$ $>0.05$; Table 3). Incertae sedis Tremellales were more abundant in conventional corn hybrids compared to $\operatorname{BMR}(\overline{\mathrm{x}}=25.8$ vs. $\overline{\mathrm{x}}=$ $13.9 \pm 3.82 \% \mathrm{RA} ; \mathrm{P}<0.05)$ while Mucoraceae were more abundant in BMR compared to conventional hybrids ( $\overline{\mathrm{x}}=7.52$ vs. $\overline{\mathrm{x}}=3.64 \pm$ 1.18; $P<0.05)$. Unidentified fungi were more abundant in MCN and MBR compared to PCN and PBR $(\overline{\mathrm{x}}=50.7$ vs. $\overline{\mathrm{x}}=38.5 \pm 3.06$; $P \leq 0.02)$ while the opposite was observed for the unidentified Ascomycota $(\overline{\mathrm{x}}=7.45$ vs. $\overline{\mathrm{x}}=18.1 \pm 2.19 ; \mathrm{P} \leq 0.01)$. More isolation 
and genetic identification work needs to be conducted to expand our knowledge of the fungal phyllosphere. Similar results were reported by Romero et al. (2018), who observed a higher abundance of unidentified fungi in MCN vs. other HYB (58.5 vs. $\overline{\mathrm{x}}=40.5 \% \mathrm{RA}$ ), an i.s. (Incertae sedis) Tremellales in PCN vs. other HYB (21.4 vs. $\overline{\mathrm{x}}=9.55)$ and unidentified Ascomycota in MBR and PBR vs. MCN and PCN ( $\overline{\mathrm{x}}=15.7$ vs. $\overline{\mathrm{x}}=6.81)$. Kong et al. (2020) also observed differences in fungal communities between three corn cultivars from different breeding sources that were cultivated in the same experimental field. Research seems to indicate that host plant genotype only contributes $4 \%$ to $8 \%$ to the variability in bacterial and fungal communities in leaves and to a lower extent in the rhizosphere depending on sampling depth (Wagner et al., 2020). The most common genera at $d 0$ in this study were Hannaella (15.0\% RA) for an i.s. Tremellales; and Mucor (5.58) for Mucoraceae. This differs from the genera reported by Keshri et al. (2018) in fresh corn which were predominantly Meyerozyma (53.3\%), Candida (27.7\%), and Cladosporium (8.2\%), most likely by cultivar, agronomic management, and environmental differences. Romero et al. (2018) also described Meyerozyma, Hannaella, Bullera, and Bulleromyces as the most abundant genera at d 0, while May et al. (2001) identified Aspergillus, Acremonium, Bullera, and Mucor by DGGE. Yeasts belonging to Hannaella genus have been previously described as inhabitants of the corn, rice, and sugarcane phyllosphere (Limtong and Nasanit, 2017; Kaewwichian et al., 2015), while Mucor are xerophilic filamentous fungi associated with spoilage that can develop in a yeast-like form that allows them to survive in anaerobic conditions (Lane et al., 2018).

\section{Silo opening (100 d)}

\section{Nutritional composition}

All nutritional composition variables at opening were affected by corn hybrid $(P \leq 0.005)$, except WSC $(P=0.33$; Table 4$)$. As observed at $\mathrm{d} 0, \mathrm{MBR}$ had the lowest DM relative to all the other hybrids ( 25.6 vs. $\overline{\mathrm{x}}=30.4 \pm 0.376 \%$; $P<0.001$ ). Likewise, $\mathrm{MBR}$ had the lowest OM concentration ( 95.5 vs. $96.6-96.9 \pm 0.08 \%$ of $\mathrm{DM} ; \mathrm{P}<0.001)$ and the highest CP $(9.31$ vs. $7.41-7.88 \pm 0.140 \%$ of DM; $P<0.001)$, and NDF (40.2 vs. $\overline{\mathrm{x}}=38.2 \pm 0.71 \%$ of DM; $\mathrm{P} \leq$ $0.05)$ when compared to the other hybrids, respectively. Across hybrids, MBR and MCN had higher levels of $\mathrm{NH}_{3}-\mathrm{N}$ relative to PCN and PBR ( $\overline{\mathrm{x}}=11.3$ vs. $\overline{\mathrm{x}}=9.9 \%$ of total N; $\mathrm{P} \leq 0.02$ ). As discussed previously, these differences are the result of the lower maturity of MBR relative to the other hybrids. Inoculation increased $\mathrm{NH}_{3}-\mathrm{N}(10.9 \%$ vs. $10.2 \%$ of total N; $P<0.02)$, NDF $(39.3$ vs. $38.1 ; P<0.05)$, $A D F(23.1$ vs. $22.3 ; P \leq 0.02)$, and $O M(96.5 \%$ vs. $96.3 \%$ of DM basis; $P<0.001)$. In the case of WSC, inoculation decreased it across all hybrids relative to CON but it did so to a larger extent for MBR (0.92 vs. 2.52), when compared to MCN and PBR ( $\overline{\mathrm{x}}=1.31$ vs. $\overline{\mathrm{x}}=2.34 \%$ of $\mathrm{DM}$, respectively; Hybrid $\times$ ADV, $P<0.05)$. Romero et al. (2018) also observed an increase in $\mathrm{NH}_{3}-\mathrm{N}(9.7 \%$ vs. $8.0 \%$ of total $\mathrm{N})$ and a decrease in WSC $(0.91 \%$ vs. $2.03 \%$ of DM) but no changes in $\mathrm{CP}, \mathrm{NDF}$, and ADF due to inoculation when compared to untreated, respectively. Bernardi et al. (2019) also reported a decrease in WSC $(2.07 \%$ vs. $2.57 \%$ of $\mathrm{DM})$ but no differences in $\mathrm{NH}_{3}-\mathrm{N}(\overline{\mathrm{x}}=4.47 \%$ of total $\mathrm{N}), \mathrm{CP}(\overline{\mathrm{x}}=$ $7.84 \%$ of DM), OM ( $\overline{\mathrm{x}}=94.9 \%$ of DM), NDF ( $\overline{\mathrm{x}}=49.7 \%$ of DM), and $\mathrm{ADF}(\overline{\mathrm{x}}=27.4 \%$ of $\mathrm{DM})$ in corn silage treated with combination inoculants like the one used in this study relative to untreated in a meta-analysis of 140 articles. However, the same authors observed that $\mathrm{NH}_{3}-\mathrm{N}$ increased in combination inoculants relative to untreated when incubation temperatures were below $25^{\circ} \mathrm{C}$, like in this study. Other studies have suggested that the increased $\mathrm{NH}_{3}-\mathrm{N}$ in L. buchneri-treated silages is associated with an increased final pH (Driehuis et al., 2001; Table 5).

\section{Fermentation measures}

The DM recovery was higher for MCN relative to PBR (97.9 vs. 94.7; $P=0.004)$ but PCN and MBR $(\overline{\mathrm{x}}=96.7 \pm 1.05 \%)$ were no different than MCN and PBR. Romero et al. (2018) reported that MBR and PBR (93.2 and 93.1) had lower DM recovery than MCN and PCN (95.8\% and 95.0\%, respectively), which is similar to what we observed in the current study with PBR. To the best of our knowledge, no studies have compared isogenic lines of BMR and conventional corn hybrids in terms of DM recovery, but it may be possible that lignification can have an effect on nutrient losses during storage (Miron et al., 2007). Further research is needed to confirm this observation. Inoculation decreased DM recovery (95.6 vs. $97.4 \pm 1.05 ; P=0.02$ ) in part due

Table 3. Relative abundance (\%) of fungal families identified from internal transcribed spacer 1 (ITS-1) region sequences extracted from chopped whole-crop corn as a function of hybrid (HYB) and silage additives (ADV) at d $0^{1}$

\begin{tabular}{|c|c|c|c|c|c|c|c|c|c|}
\hline \multirow[b]{2}{*}{ Item } & \multicolumn{4}{|c|}{ Hybrid } & \multirow[b]{2}{*}{ Mean } & \multirow[b]{2}{*}{ SEM } & \multicolumn{3}{|c|}{$P$-value } \\
\hline & MCN & PCN & MBR & PBR & & & HYB & ADV & $\mathrm{HYB} \times \mathrm{ADV}$ \\
\hline Unidentified fungi & $50.7^{\mathrm{a}}$ & $37.5^{b}$ & $50.6^{a}$ & $39.4^{\mathrm{b}}$ & & 3.13 & 0.003 & 0.681 & 0.970 \\
\hline Incertae sedis Tremellales & $26.0^{\mathrm{a}}$ & $25.6^{\mathrm{a}}$ & $14.6^{\mathrm{b}}$ & $13.1^{\mathrm{b}}$ & & 3.91 & 0.032 & 0.359 & 0.466 \\
\hline Unidentified Ascomycota & $5.80^{\mathrm{b}}$ & $18.8^{\mathrm{a}}$ & $9.10^{\mathrm{b}}$ & $17.3^{\mathrm{a}}$ & & 2.25 & $<0.001$ & 0.180 & 0.779 \\
\hline Mucoraceae & $3.12^{\mathrm{b}}$ & $4.16^{\mathrm{b}}$ & $7.47^{\mathrm{a}}$ & $7.56^{\mathrm{a}}$ & & 1.18 & 0.016 & 0.689 & 0.256 \\
\hline Nectriaceae & - & - & - & - & 3.32 & 0.494 & 0.094 & 0.140 & 0.232 \\
\hline Unidentified Pleosporales & $2.23^{c}$ & $1.59^{\mathrm{d}}$ & $3.00^{\mathrm{b}}$ & $4.23^{\mathrm{a}}$ & & 0.191 & $<0.001$ & 0.165 & 0.130 \\
\hline Incertae sedis Saccharomycetales & $0.864^{c}$ & $4.93^{\mathrm{a}}$ & $0.440^{c}$ & $3.72^{\mathrm{b}}$ & & 0.425 & $<0.001$ & 0.256 & 0.467 \\
\hline Pleosporaceae & $1.04^{c}$ & $0.611^{c}$ & $3.78^{\mathrm{a}}$ & $2.73^{b}$ & & 0.240 & $<0.001$ & 0.326 & 0.896 \\
\hline Unidentified Dothideomycetes & $0.686^{b}$ & $0.632^{b}$ & $1.80^{\mathrm{a}}$ & $1.79^{\mathrm{a}}$ & & 0.123 & $<0.001$ & 0.339 & 0.561 \\
\hline Phaeosphaeriaceae & $0.938^{c}$ & $0.551^{d}$ & $1.32^{\mathrm{b}}$ & $1.91^{\mathrm{a}}$ & & 0.127 & $<0.001$ & 0.353 & 0.486 \\
\hline Pichiaceae & $0.084^{b}$ & $0.077^{b}$ & $0.054^{b}$ & $0.218^{\mathrm{a}}$ & & 0.048 & 0.025 & 0.964 & 0.721 \\
\hline
\end{tabular}

${ }^{1} \mathrm{MCN}, \mathrm{PCN}, \mathrm{MBR}$, and PBR corn hybrids are TMF2R737, P2089YHR, F2F817, and P1449XR, respectively. Hybrids MCN and MBR are property of Mycogen Seeds (Indianapolis, IN) and hybrids PCN and PBR are property of Pioneer Hi-Bred International (Johnston, IA). MBR and PBR are brown midrib hybrids. CON, control (water); INO, inoculant (Biotal Buchneri 500; Lallemand Animal Nutrition, Milwaukee, WI) delivering L. buchneri 40788 and P. pentosaceus at 400,000 and 100,000 cfu/g of fresh corn, respectively.

a-d Means with different superscripts within a row are significantly different $(P \leq 0.05)$. 
8 | Journal of Animal Science, 2021, Vol. 99, No. 8

Table 4. Nutritional composition of chopped whole-crop corn as a function of hybrid (HYB) and silage additives (ADV) at d $100^{1}$

\begin{tabular}{|c|c|c|c|c|c|c|c|c|c|}
\hline \multirow[b]{2}{*}{ Item } & \multicolumn{4}{|c|}{ Hybrid } & \multirow[b]{2}{*}{ Mean } & \multirow[b]{2}{*}{ SEM } & \multicolumn{3}{|c|}{$P$-value } \\
\hline & $\mathrm{MCN}$ & PCN & MBR & PBR & & & HYB & ADV & $\mathrm{HYB} \times \mathrm{ADV}$ \\
\hline $\mathrm{DM}, \%$ & $30.4^{\mathrm{a}}$ & $30.5^{\mathrm{a}}$ & $25.6^{\mathrm{b}}$ & $30.2^{\mathrm{a}}$ & - & 0.376 & $<0.001$ & 0.112 & 0.694 \\
\hline $\mathrm{OM}, \%$ of $\mathrm{DM}$ & & & & & - & 0.066 & $<0.001$ & $<0.001$ & 0.088 \\
\hline $\mathrm{CON}$ & - & - & - & - & $96.3^{\mathrm{B}}$ & & & & \\
\hline INO & - & - & - & - & $96.5^{\mathrm{A}}$ & & & & \\
\hline Mean & $96.7^{b}$ & $96.9^{\mathrm{a}}$ & $95.5^{c}$ & $96.6^{\mathrm{b}}$ & & & & & \\
\hline $\mathrm{CP}, \%$ of $\mathrm{DM}$ & $7.41^{\mathrm{c}}$ & $7.88^{\mathrm{b}}$ & $9.31^{\mathrm{a}}$ & $7.63^{b c}$ & - & 0.140 & $<0.001$ & 0.673 & 0.863 \\
\hline $\mathrm{NH}_{3}-\mathrm{N}, \%$ of $\mathrm{DM}^{2}$ & & & & & & 0.0050 & $<0.001$ & 0.029 & 0.057 \\
\hline $\mathrm{CON}$ & - & - & - & - & $0.132^{\mathrm{B}}$ & & & & \\
\hline INO & - & - & - & - & $0.140^{\mathrm{A}}$ & & & & \\
\hline Mean & $0.134^{b}$ & $0.122^{c}$ & $0.166^{\mathrm{a}}$ & $0.122^{c}$ & & & & & \\
\hline $\mathrm{NH}_{3}-\mathrm{N}, \%$ of total $\mathrm{N}$ & & & & & & 0.43 & $<0.001$ & 0.020 & 0.129 \\
\hline $\mathrm{CON}$ & - & - & - & - & $10.2^{\mathrm{B}}$ & & & & \\
\hline INO & _- & _- & _- & _- & $10.9^{\mathrm{A}}$ & & & & \\
\hline Mean & $11.3^{\mathrm{a}}$ & $9.7^{b}$ & $11.2^{\mathrm{a}}$ & $10.1^{\mathrm{b}}$ & & & & & \\
\hline WSC, $\%$ of $\mathrm{DM}^{3}$ & & & & & & 0.165 & 0.329 & $<0.001$ & 0.038 \\
\hline $\mathrm{CON}$ & $2.16^{\mathrm{A}}$ & $2.06^{\mathrm{A}}$ & $2.52^{\mathrm{A}}$ & $2.52^{\mathrm{A}}$ & 2.31 & & & & \\
\hline INO & $1.40^{\mathrm{B}, \mathrm{a}}$ & $1.15^{\mathrm{B}, \mathrm{ab}}$ & $0.92^{\mathrm{B}, \mathrm{b}}$ & $1.22^{\mathrm{B}, \mathrm{a}}$ & 1.16 & & & & \\
\hline NDF, \% of DM & & & & & & 0.71 & 0.005 & 0.029 & 0.333 \\
\hline $\mathrm{CON}$ & - & - & - & - & $38.1^{\mathrm{B}}$ & & & & \\
\hline INO & - & - & - & - & $39.3^{\mathrm{A}}$ & & & & \\
\hline Mean & $38.8^{\mathrm{ab}}$ & $37.7^{b}$ & $40.2^{\mathrm{a}}$ & $38.0^{\mathrm{b}}$ & & & & & \\
\hline $\mathrm{ADF}, \%$ of $\mathrm{DM}$ & & & & & & 0.44 & $<0.001$ & 0.013 & 0.134 \\
\hline $\mathrm{CON}$ & - & - & - & - & $22.3^{\mathrm{B}}$ & & & & \\
\hline INO & _- & _- & _- & _- & $23.1^{\mathrm{A}}$ & & & & \\
\hline Mean & $23.7^{\mathrm{a}}$ & $21.6^{c}$ & $23.1^{\mathrm{ab}}$ & $22.5^{\mathrm{b}}$ & & & & & \\
\hline
\end{tabular}

${ }^{1} \mathrm{MCN}, \mathrm{PCN}, \mathrm{MBR}$, and PBR corn hybrids are TMF2R737, P2089YHR, F2F817, and P1449XR, respectively. Hybrids MCN and MBR are property of Mycogen Seeds (Indianapolis, IN) and PCN and PBR are property of Pioneer Hi-Bred International (Johnston, IA). CON, control (water); INO, inoculant (Biotal Buchneri 500; Lallemand Animal Nutrition, Milwaukee, WI) delivering L. buchneri 40788 and P. pentosaceus at 400,000 and $100,000 \mathrm{cfu} / \mathrm{g}$ of fresh corn, respectively.

${ }^{2} \mathrm{NH}_{3}-\mathrm{N}$, ammonia-N.

${ }^{3}$ WSC, Water soluble carbohydrates.

${ }_{A, B}$ Means with different uppercase superscripts within a column are significantly different $(P \leq 0.05)$.

${ }^{a-c}$ Means with different lowercase superscripts within a row are significantly different $(P \leq 0.05)$.

to a large increase in acetic acid production when compared to CON (3.44 vs. $1.32 \pm 0.346 ; P<0.001$ ), respectively. Consequently, INO reduced lactic acid concentration relative to $\mathrm{CON}$ in PCN (4.28 vs. 6.35), MBR (2.98 vs. 9.06), and PBR (5.42 vs. 7.52), but not in $\mathrm{MCN}(\overline{\mathrm{x}}=4.94 \pm 0.592$, respectively; Hybrid $\times$ ADV, $P<0.001)$ and consequently decreased the lactic to acetic acid ratio (L:A) compared to CON (1.51 vs. 5.58, respectively; $P<0.001$ ). This is explained by L. buchneri conversion of lactic acid into acetic acid and 1,2 propanediol (Oude Elferink et al., 2001). Since acetic acid is a weaker acid relative to lactic acid ( 4.75 and $3.86 \mathrm{pKa}$, respectively; Bruice, 2004), L. buchneri activity also increased the pH of INO-treated MCN, PCN, and MBR relative to $\operatorname{CON}(3.97,3.98$, and 4.21 vs. $\overline{\mathrm{x}}=3.85$, respectively) but not of $\mathrm{PBR}(\overline{\mathrm{x}}=3.89 \pm 0.032$; Hybrid $\times$ ADV, $P<0.001)$. Conversely, ethanol concentration was only reduced by INO when compared to CON in PBR (0.83 vs. 1.25 , respectively) but not in the other hybrids ( $\bar{x}=0.62 \pm 0.083 \%$ of DM; Hybrid $\times A D V, P=0.009)$. This may be because untreated PBR had the highest ethanol levels compared to untreated MCN, PCN, and MBR ( $1.25 \%$ vs. $0.63 \%, 0.70 \%$, and $0.43 \%$ of DM, respectively; Hybrid $\times A D V, P=0.009$ ). Inoculated silages were the only ones with measurable levels of 1,2-propanediol (detection limit was $0.014 \%$ of DM) as a result of the metabolic activity of L. buchneri on lactic acid. The concentration was especially high in MBR (1.20), but no different than CON in PBR $(0.28 \pm 0.110 \%$ of $\mathrm{DM}$; Hybrid $\times \mathrm{ADV}, \mathrm{P}<0.001)$. Propionic and butyric acids were not detectable in this study for any treatment $(<0.014 \%$ of $\mathrm{DM})$.
Across corn hybrids, INO increased acetic acid (3.44 vs. $1.32 \pm$ $0.346)$ and decreased DM recovery (95.6 vs. $97.4 \pm 1.05 \%$ ) and the L:A ratio ( 1.51 vs. 5.58; $P<0.001)$. Similarly, Romero et al. (2018) reported an increase in acetic acid (1.69 vs. 0.51) and 1,2-propanediol (0.78 vs. 0.01) and a decrease in lactic acid $(2.65 \%$ vs. $4.82 \%$ of DM) and the L:A ratio (1.9 vs. 9.8 ) but no change on DM recovery $(\overline{\mathrm{x}}=94.3 \%)$ due to inoculation relative to CON. In the meta-analysis conducted by Bernardi et al. (2019), it was reported that corn silage treated with combination inoculants reduced DM recovery ( $94.8 \%$ vs. $95.8 \%)$, and increased acetic acid (1.75 vs. 1.37 ) and 1,2-propanediol (1.00\% vs. $0.153 \%$ of DM) but had no effect on $\mathrm{pH}(\overline{\mathrm{x}}=3.82)$, lactic acid (4.47), and ethanol (8.78) relative to untreated, respectively. However, an increased $\mathrm{pH}$ (3.84 vs. 3.81) and acetic acid (2.72 vs. 1.37 ) and decreased lactic acid concentrations ( $2.86 \%$ vs. $4.22 \%$ of $\mathrm{DM})$ were observed in corn silage treated with obligate heterolactic bacteria inoculants relative to untreated (Bernardi et al., 2019). We believe that our results are similar to the obligate heterolactic bacteria inoculant group in Bernardi et al. (2019) because the acetic acid concentration for INO in our study was even higher $(3.44 \%$ of $\mathrm{DM})$ and would have released even more $\mathrm{CO}_{2}$ to the atmosphere.

Microbial population and aerobic stability

We found no corn hybrid effects on LAB ( $\overline{\mathrm{x}}=8.18 \pm 0.288)$, yeast $(\overline{\mathrm{x}}=3.81 \pm 0.446)$, and mold counts $(\overline{\mathrm{x}}=2.24 \pm 0.614 \mathrm{log} \mathrm{cfu} / \mathrm{g}$ of FW) at silo opening $(P>0.09$; Table 6$)$. Addition of INO increased 
Table 5. Fermentation measures of chopped whole corn as a function of hybrid (HYB) and silage additives (ADV) at d 1001

\begin{tabular}{|c|c|c|c|c|c|c|c|c|c|}
\hline \multirow[b]{2}{*}{ Item } & \multicolumn{4}{|c|}{ Hybrid } & \multirow[b]{2}{*}{ Mean } & \multirow[b]{2}{*}{ SEM } & \multicolumn{3}{|c|}{$P$-value } \\
\hline & MCN & PCN & MBR & PBR & & & HYB & ADV & $\mathrm{HYB} \times \mathrm{ADV}$ \\
\hline \multicolumn{6}{|c|}{ DM recovery, \% } & 1.05 & 0.035 & 0.016 & 0.820 \\
\hline $\mathrm{CON}$ & - & - & - & - & $97.4^{\mathrm{A}}$ & & & & \\
\hline INO & - & - & - & - & $95.6^{\mathrm{B}}$ & & & & \\
\hline Mean & $97.9^{\mathrm{a}}$ & $96.8^{\mathrm{ab}}$ & $96.5^{\mathrm{ab}}$ & $94.7^{\mathrm{b}}$ & & & & & \\
\hline \multicolumn{6}{|l|}{$\mathrm{pH}$} & 0.032 & $<0.001$ & $<0.001$ & $<0.001$ \\
\hline $\mathrm{CON}$ & $3.86^{\mathrm{B}}$ & $3.84^{\mathrm{B}}$ & $3.84^{\mathrm{B}}$ & 3.85 & & & & & \\
\hline INO & $3.97^{\mathrm{A}, \mathrm{b}}$ & $3.98^{\mathrm{A}, \mathrm{b}}$ & $4.21^{\mathrm{A}, \mathrm{a}}$ & $3.93^{\mathrm{b}}$ & & & & & \\
\hline \multicolumn{6}{|c|}{ Lactic acid (L), \% of DM } & 0.592 & 0.058 & $<0.001$ & $<0.001$ \\
\hline $\mathrm{CON}$ & $5.53^{\mathrm{c}}$ & $6.35^{\mathrm{A}, \mathrm{bc}}$ & $9.06^{\mathrm{A}, \mathrm{a}}$ & $7.52^{\mathrm{A}, \mathrm{ab}}$ & & & & & \\
\hline INO & $4.35^{\mathrm{ab}}$ & $4.28^{\mathrm{B}, \mathrm{ab}}$ & $2.98^{\mathrm{B}, \mathrm{b}}$ & $5.42^{\mathrm{B,a}}$ & & & & & \\
\hline \multicolumn{6}{|c|}{ Acetic acid (A), \% of DM } & 0.346 & 0.142 & $<0.001$ & 0.323 \\
\hline $\mathrm{CON}$ & - & - & - & - & $1.32^{\mathrm{B}}$ & & & & \\
\hline INO & - & - & - & - & $3.44^{\mathrm{A}}$ & & & & \\
\hline \multicolumn{6}{|c|}{ 1,2-propanediol, \% of DM } & 0.110 & $<0.001$ & $<0.001$ & $<0.001$ \\
\hline $\mathrm{CON}$ & $0.00^{\mathrm{B}}$ & $0.00^{\mathrm{B}}$ & $0.00^{\mathrm{B}}$ & 0.00 & & & & & \\
\hline INO & $0.49^{\mathrm{A}, \mathrm{b}}$ & $0.45^{\mathrm{A}, \mathrm{b}}$ & $1.20^{\mathrm{A}, \mathrm{a}}$ & $0.28^{\mathrm{b}}$ & & & & & \\
\hline \multicolumn{6}{|c|}{ Ethanol (E), \% of DM } & 0.083 & $<0.001$ & 0.338 & 0.009 \\
\hline $\mathrm{CON}$ & $0.63^{b}$ & $0.70^{\mathrm{b}}$ & $0.43^{c}$ & $1.25^{\mathrm{A}, \mathrm{a}}$ & & & & & \\
\hline INO & $0.65^{\mathrm{a}, \mathrm{b}}$ & $0.79^{\mathrm{a}}$ & $0.52^{\mathrm{b}}$ & $0.83^{\mathrm{B}, \mathrm{a}}$ & & & & & \\
\hline \multicolumn{6}{|l|}{ L:A ratio ${ }^{2}$} & 0.522 & 0.972 & $<0.001$ & 0.115 \\
\hline $\mathrm{CON}$ & - & - & - & - & $5.58^{\mathrm{A}}$ & & & & \\
\hline INO & - & - & - & - & $1.51^{\mathrm{B}}$ & & & & \\
\hline \multicolumn{6}{|c|}{$\mathrm{L}:(\mathrm{A}+\mathrm{OH})$ ratio $^{3}$} & 0.290 & 0.450 & $<0.001$ & $<0.001$ \\
\hline $\mathrm{CON}$ & $3.13^{\mathrm{A}, \mathrm{b}}$ & $3.58^{\mathrm{A}, \mathrm{b}}$ & $4.56^{\mathrm{A}, \mathrm{a}}$ & $2.84^{\mathrm{A}, \mathrm{b}}$ & & & & & \\
\hline INO & $1.28^{\mathrm{B}}$ & $0.84^{\mathrm{B}}$ & $0.55^{\text {B }}$ & $1.40^{\mathrm{B}}$ & & & & & \\
\hline
\end{tabular}

${ }^{1}$ MCN, PCN, MBR, and PBR corn hybrids are TMF2R737, P2089YHR, F2F817, and P1449XR, respectively. Hybrids MCN and MBR are property of Mycogen Seeds (Indianapolis, IN) and PCN and PBR are property of Pioneer Hi-Bred International (Johnston, IA). CON, control (water); INO, inoculant (Biotal Buchneri 500; Lallemand Animal Nutrition, Milwaukee, WI) delivering L. buchneri 40788 and P. pentosaceus at 400,000 and $100,000 \mathrm{cfu} / \mathrm{g}$ of fresh corn, respectively.

${ }^{2} \mathrm{~L}$, lactic acid; A, acetic acid.

${ }^{3} \mathrm{~L}$, lactic acid; A, acetic acid; OH, ethanol plus 1,2-propanediol.

A,BMeans with different uppercase superscripts within a column are significantly different $(P \leq 0.05)$.

${ }^{a-c}$ Means with different lowercase superscripts within a row are significantly different $(P \leq 0.05)$.

LAB (9.30 vs. $7.05 \pm 0.288 \mathrm{log} \mathrm{cfu} / \mathrm{g}$ of $\mathrm{FW})$ and decreased yeast ( 3.05 vs. $4.58 \pm 0.446 \mathrm{log} \mathrm{cfu} / \mathrm{g}$ of FW) and mold counts (1.51 vs. $2.96 \pm 0.614 \log \mathrm{cfu} / \mathrm{g}$ of FW) when compared to CON across all hybrids $(P<0.002)$. The reduction in yeasts and molds resulted in an extended aerobic stability across all hybrids when INO was applied relative to CON (582 vs. $111 \pm 128 \mathrm{~h} ; \mathrm{P}<0.001)$, because of an increase in acetic acid concentration which acts as an antifungal agent. All INO hybrids were aerobically stable for more than $168 \mathrm{~h}$, which is the minimum recommended time to keep silages aerobically stable (Wilkinson and Davies, 2013). Bernardi et al. (2019) also reported an increase in LAB (6.87 vs. 6.70 ) and a decrease in yeast counts (2.89 vs. $4.01 \mathrm{log} \mathrm{cfu} / \mathrm{g}$ of FW) that led to an extended aerobic stability (77.8 vs. $67.7 \mathrm{~h}$ ) in corn silage treated with combination inoculants relative to untreated. Romero et al. (2018) also reported no effects of hybrid on $\operatorname{LAB}(\overline{\mathrm{x}}=6.43)$, yeast $(\overline{\mathrm{x}}=4.46)$, and mold counts $(\overline{\mathrm{x}}$ $=0.42 \log \mathrm{cfu} / \mathrm{g}$ of FW) after $100 \mathrm{~d}$ of ensiling and at $36.1 \%$ to 42.7\% DM. In that study, inoculation also increased LAB (6.59 vs. 6.26) and decreased yeast counts relative to untreated ( 3.78 vs. $5.13 \mathrm{log} \mathrm{cfu} / \mathrm{g}$ of FW), respectively, but had no effects on mold counts possibly due to lower production of acetic acid ( $\overline{\mathrm{x}}$ $=1.69 \%$ of DM) in inoculated silages relative to this study. This decrease in yeast counts resulted also in an extended aerobic stability for all inoculated hybrids compared to untreated (217 vs. 34.7, respectively), except for MBR ( $\overline{\mathrm{x}}=49 \mathrm{~h}$; Romero et al., 2018). Key differences explain the success of INO in preserving
MBR in this study relative to Romero et al. (2018). First, our INO-treated MBR had $3.97 \%$ of $\mathrm{DM}$ acetic acid compared to the $1.60 \%$ of DM found in Romero et al. (2018), which in part is explained by the differences in DM for MBR between our current study and Romero et al. (2018; $25.6 \%$ vs. $36.1 \%$, respectively). Concentrations of acetic acid above $3 \%$ of DM typically ensure adequate aerobic stability due to antifungal activity (Kung et al., 2018). Second, in spite of both studies having the same ensiling time $(100 \mathrm{~d})$ and incubation temperature $\left(23^{\circ} \mathrm{C}\right)$, higher residual lactic acid levels were observed in the INO-treated MBR relative to the other INO-treated hybrids (4.63 vs. $\overline{\mathrm{x}}=1.99 \%$ of $\mathrm{DM}$, respectively) in Romero et al. (2018), while in this study INOtreated MBR (2.98\% of DM) was no different than INO-treated MCN and PCN and even lower than PBR. Third, we speculate that the high abundance of Leuconostocaceae in the untreated MBR relative to the other untreated hybrids at d 100 in Romero et al. (28.7 vs. 9.72 RA\%; 2018) seems to suggest that L. buchneri may have had a much more stringent competition from other bacteria which may have affected its ability to convert lactic acid to acetic acid efficiently. Such difference in the RA of Leuconostocaceae was not observed for MBR in this study (Table 7). Furthermore, Leuconostocaceae members such as Leunostoc mesenteroides are known to produce bacteriocins that affect the growth of other lactic acid bacteria (Mataragas et al., 2002).

We found that INO reduced bacterial observed OTUs (66 vs. $226 \pm 10.7)$ and phylogenetic diversity ( 6.75 vs. $14.4 \pm 0.60$; 
Table 6. Microbial counts and aerobic stability of chopped whole corn as a function of hybrid (HYB) and silage additives (ADV) at d 100

\begin{tabular}{|c|c|c|c|c|c|c|c|c|c|}
\hline \multirow[b]{2}{*}{ Item } & \multicolumn{4}{|c|}{ Hybrid } & \multirow[b]{2}{*}{ Mean } & \multirow[b]{2}{*}{ SEM } & \multicolumn{3}{|c|}{$P$-value } \\
\hline & MCN & PCN & MBR & PBR & & & HYB & ADV & $\mathrm{HYB} \times \mathrm{ADV}$ \\
\hline \multicolumn{6}{|c|}{$\begin{array}{l}\text { Lactic acid bacteria, log cfu/g of } \\
\text { FW }^{2}\end{array}$} & 0.288 & 0.121 & $<0.001$ & 0.387 \\
\hline $\mathrm{CON}$ & - & - & - & - & $7.05^{\mathrm{B}}$ & & & & \\
\hline INO & - & - & - & - & $9.30^{\mathrm{A}}$ & & & & \\
\hline \multicolumn{6}{|c|}{$\begin{array}{l}\text { Yeast, } \log \mathrm{cfu} / \mathrm{g} \text { of } \\
\text { FW }\end{array}$} & 0.446 & 0.103 & $<0.001$ & 0.456 \\
\hline $\mathrm{CON}$ & - & - & - & - & $4.58^{\mathrm{A}}$ & & & & \\
\hline INO & - & - & - & - & $3.05^{\mathrm{B}}$ & & & & \\
\hline \multicolumn{6}{|c|}{$\begin{array}{l}\text { Molds, log cfu/g of } \\
\text { FW }\end{array}$} & 0.614 & 0.088 & 0.002 & 0.631 \\
\hline $\mathrm{CON}$ & - & - & - & - & $2.96^{\mathrm{A}}$ & & & & \\
\hline INO & - & - & - & - & $1.51^{\mathrm{B}}$ & & & & \\
\hline \multicolumn{6}{|c|}{ Aerobic stability, $\mathrm{h}$} & 128 & 0.078 & $<0.001$ & 0.439 \\
\hline $\mathrm{CON}$ & - & - & - & - & $111^{\mathrm{B}}$ & & & & \\
\hline INO & - & - & - & - & $582^{A}$ & & & & \\
\hline
\end{tabular}

${ }^{1} \mathrm{MCN}, \mathrm{PCN}, \mathrm{MBR}$, and PBR corn hybrids are TMF2R737, P2089YHR, F2F817, and P1449XR, respectively. Hybrids MCN and MBR are property of Mycogen Seeds (Indianapolis, IN) and PCN and PBR are property of Pioneer Hi-Bred International (Johnston, IA). MBR and PBR are brown midrib hybrids. CON, control (water); INO, inoculant (Biotal Buchneri 500; Lallemand Animal Nutrition, Milwaukee, WI) delivering L. buchneri 40788 , and P. pentosaceus at 400,000 and 100,000 cfu/g of fresh corn, respectively.

${ }^{2} \mathrm{FW}$, fresh corn

A,BMeans with different uppercase superscripts within a column are significantly different $(P \leq 0.05)$.

$P<0.001)$ compared to CON but increased fungal observed OTUs vs. CON ( 46 vs. $20 \pm 2.95 ; P<0.01$ ). These results suggest that INO reduces the bacterial and increases fungal diversity consistently across all ensiled hybrids tested in this study even though richness differences between hybrids were observed at d 0. Likewise, Romero et al. (2018) also observed decreased bacterial and increased fungal OTUs for INO vs. CON. By evaluating Heip's evenness index we observed that fungal OTUs abundance was more evenly distributed in INO compared to CON (0.093 vs. $0.042 \pm 0.011 ; P=0.003)$. Conversely, bacterial OTUs abundance was more evenly distributed in CON vs. INO-treated hybrids ( $\overline{\mathrm{x}}=0.030$ vs. $\overline{\mathrm{x}}=0.011 \pm 0.004)$. Furthermore, within CON hybrids, PBR was more even relative to MBR (0.044 vs. 0.019; $H Y B \times A D V ; P=0.009)$. Further research should be conducted to understand the effects of inoculants on silage fungal diversity. The weighted UniFrac (Figure 1) and Bray-Curtis (Figure 2) principal coordinates analysis plots indicated a separation and difference in the structure of the bacterial $(P=0.001)$ and fungal $(P=0.001)$ communities between the CON and INO at $d 100$, and between $d 0$ and d $100(P=0.001)$, according to analysis of similarities test of distance metrics. This same trend was also observed by Romero et al. (2018) for both bacterial and fungal communities. INO treatment increased Lactobacillaceae RA compared to CON (99.2 vs. $75.7 \pm 2.98 ; P<0.001)$ and decreased Enterobacteriaceae $(0.277$ vs. $9.93 \pm 1.28 ; P<0.001)$, Lachnospiraceae (0.034 vs. $1.71 \pm 0.576 ; P<0.05)$, Xanthomonadaceae (0.031 vs. $0.980 \pm 0.124 ; P<0.001$ ), Moraxellaceae ( 0.025 vs. $1.01 \pm 0.153$; $P<0.001)$, and Paenibacillaceae (0.019 vs. $1.34 \pm 0.647 ; P<0.05)$. INO had a lower RA of Leuconostocaceae vs. CON only for PBR $(0.21$ vs. 14.5$)$ but not for other HYB ( $\bar{x}=0.21$ vs. $\bar{x}=2.70 \pm 1.87$; HYB $\times$ INO, $P=003)$. Similarly, Romero et al. (2018) found an increased Lactobacillaceae RA in INO-treated silages compared with CON $(\overline{\mathrm{x}}=98.9$ vs. $\overline{\mathrm{x}}=52.7 \%)$, especially for MBR, which had a lower RA in untreated silages compared with the other untreated hybrids (34.3 vs. $\overline{\mathrm{x}}=58.9$ ). The RA of Enterobacteriaceae was also decreased by the application of INO compared to CON ( $\overline{\mathrm{x}}=23.5$ vs. $\overline{\mathrm{x}}=0.614 \%$ ) in that study. The major bacterial genera identified at d 100, were Lactobacillus and Pediococcus for Lactobacillaceae; unidentified genus and Cronobacter for Enterobacteriaceae, and unidentified genus and Leuconostoc for Leuconostocaceae. The high abundance of Enterobacteriaceae at d 0 is expectedly replaced by Lactobacillaceae in grass silages (Borreani et al., 2018), especially consisting of the Lactobacillus genus, as reported by various authors by NGS in treated and untreated whole-crop corn silage (Keshri et al., 2018; Xu et al., 2019; Guan et al., 2020). The selection and proliferation of Lactobacillaceae in corn silage can occur as early as $3 \mathrm{~h}$ after ensiling (Keshri et al., 2018) and reach a relative abundance of $79.7 \%$ to $96.1 \%$ after 3 days (Gharechahi et al., 2017). At the genus level, Keshri et al. (2018) described an initial dominance of Weissella, Acinetobacter, and Pantoea until d 1 of ensiling, when dominance is overtaken by Lactobacillus in untreated silages and to a larger extent in silages treated with L. plantarum. Microbial dynamics during the first days of ensiling are critical for the development of good quality silage because lactic acid bacteria compete with enterobacteria for nutrients (Pahlow et al., 2003). Inoculants combining P. pentosaceus and L. buchneri have shown rapid $\mathrm{pH}$ declines and dominance of the early fermentation stages in silages compared to untreated silages (Muck et al., 2018). These results reinforce the knowledge that LAB inoculants improve the quality and aerobic stability of corn silage by enhancing the microbial composition and limiting the growth of undesirable microorganisms (Blajman et al., 2018; Xu et al., 2019). It is also noticeable that the Lactobacillaceae RA of untreated silages in this study is higher and Enterobacteriaceae RA is lower than for Romero et al. (2018) at d 100, which could be attributed to the differences in silage DM content, phyllosphere, and agronomic management, between these studies. This was also observed by McEniry et al. (2010) who evaluated microbial counts and reported a higher rate of increase of lactic acid bacteria (4.6 log CFU/g of herbage increase in $14 \mathrm{~d}$ ) and rate of decrease of enterobacteria (3.04 decrease in $14 \mathrm{~d})$ in low-DM (18.5\%) vs. high-DM (40.6\%; 1.9 increase and 2.5 decrease in $14 \mathrm{~d}$, respectively) perennial ryegrass silages. The presence of Clostridiaceae in silages is undesirable due to 
Table 7. Relative abundance (\%) of bacterial families identified from $16 \mathrm{~S}$ ribosomal DNA sequences extracted from chopped whole-crop corn as a function of hybrid (HYB) and silage additives (ADV) at d $100^{1}$

\begin{tabular}{|c|c|c|c|c|c|c|c|c|c|}
\hline \multirow[b]{2}{*}{ Item } & \multicolumn{4}{|c|}{ Hybrid } & \multirow[b]{2}{*}{ Mean } & \multirow[b]{2}{*}{ SEM } & \multicolumn{3}{|c|}{$P$-value } \\
\hline & $\mathrm{MCN}$ & PCN & MBR & PBR & & & HYB & ADV & $\mathrm{HYB} \times \mathrm{ADV}$ \\
\hline Lactobacillaceae & & & & & & 3.09 & 0.164 & $<0.001$ & 0.174 \\
\hline $\mathrm{CON}$ & - & - & - & - & $75.7^{\mathrm{B}}$ & & & & \\
\hline INO & - & - & - & - & $99.2^{\mathrm{A}}$ & & & & \\
\hline Enterobacteriaceae & & & & & & 1.32 & 0.686 & $<0.001$ & 0.753 \\
\hline $\mathrm{CON}$ & - & - & - & - & $9.93^{\mathrm{A}}$ & & & & \\
\hline INO & - & - & - & - & $0.277^{\text {в }}$ & & & & \\
\hline Leuconostocaceae & & & & & & 1.87 & 0.003 & $<0.001$ & 0.003 \\
\hline CON & $3.37^{\mathrm{b}}$ & $3.19^{\mathrm{b}}$ & $1.55^{\mathrm{b}}$ & $14.52^{\mathrm{A}, \mathrm{a}}$ & & & & & \\
\hline INO & 0.298 & 0.164 & 0.159 & $0.209^{B}$ & & & & & \\
\hline Lachnospiraceae & & & & & & 0.60 & 0.315 & 0.047 & 0.333 \\
\hline $\mathrm{CON}$ & - & - & - & - & $1.71^{\mathrm{A}}$ & & & & \\
\hline INO & - & - & - & - & $0.034^{\mathrm{B}}$ & & & & \\
\hline Xanthomonadaceae & & & & & & 0.128 & 0.381 & $<0.001$ & 0.387 \\
\hline $\mathrm{CON}$ & - & - & - & - & $0.980^{\mathrm{A}}$ & & & & \\
\hline INO & - & - & - & - & $0.031^{\mathrm{B}}$ & & & & \\
\hline Moraxellaceae & & & & & & 0.158 & 0.135 & $<0.001$ & 0.135 \\
\hline $\mathrm{CON}$ & - & - & - & - & $1.01^{\mathrm{A}}$ & & & & \\
\hline INO & - & - & - & - & $0.025^{\mathrm{B}}$ & & & & \\
\hline Paenibacillaceae & & & & & & 0.655 & 0.047 & 0.049 & 0.051 \\
\hline $\mathrm{CON}$ & - & - & - & - & $1.34^{\mathrm{A}}$ & & & & \\
\hline INO & - & - & - & - & $0.019^{\mathrm{B}}$ & & & & \\
\hline Mean & $0.083^{b}$ & $0.141^{b}$ & $0.136^{\mathrm{b}}$ & $2.35^{\mathrm{a}}$ & & & & & \\
\hline Clostridiaceae & - & - & - & - & 0.252 & 0.329 & 0.377 & 0.196 & 0.314 \\
\hline
\end{tabular}

${ }^{1} \mathrm{MCN}, \mathrm{PCN}, \mathrm{MBR}$, and PBR corn hybrids are TMF2R737, P2089YHR, F2F817, and P1449XR, respectively. Hybrids MCN and MBR are property of Mycogen Seeds (Indianapolis, IN) and hybrids PCN and PBR are property of Pioneer Hi-Bred International (Johnston, IA). CON, control (water); INO, inoculant (Biotal Buchneri 500; Lallemand Animal Nutrition, Milwaukee, WI) delivering L. buchneri 40788 and P. pentosaceus at 400,000 and $100,000 \mathrm{cfu} / \mathrm{g}$ of fresh corn, respectively.

$\mathrm{A}, \mathrm{B}$ Means with different uppercase superscripts within a column are significantly different $(\mathrm{P} \leq 0.05)$.

${ }^{\mathrm{a}-\mathrm{d} M e a n s}$ with different superscripts within a row are significantly different $(P \leq 0.05)$.

their capacity to produce butyric acid and promote the growth of spoilage microorganisms (Duniere et al., 2017), nevertheless, minimal abundance of Clostridiaceae $(0.252 \% \mathrm{RA})$ was found in this study most likely due to the low $\mathrm{pH}$ typical of whole-crop corn silage.

For fungi, we observed a higher RA of phylum Ascomycota (83.5), followed by a reduced presence of Basidiomycota (12.2) and Zygomycota (1.7\%). INO decreased Monascaceae vs. CON (12.6 vs. $44.7 \pm 8.27 ; P=0.006)$ as well as an i.s. Tremellales (0.076 vs. $0.903 \pm 1.311 ; P=0.002)$, but increased an i.s. Saccharomycetales (6.39 vs. $0.250 \pm 1.72 ; P<0.001)$, unidentified fungi (2.04 vs. $0.044 \pm 0.60 ; P<0.001$ ), and Pichiaceae (0.305 vs. $0.056 \pm 0.090 \% ; P=0.005 ;$ Table 8$)$. A significant HYB effect was observed for Saccharomycetaceae $(P<0.02)$, due to a lower RA for MBR (9.95) compared to the other corn hybrids ( $\overline{\mathrm{x}}=$ 51.1\%). A HYB $\times$ ADV interaction was observed for Mucoraceae and unidentified Pleosporales because the application of INO increased their RA compared to CON for PCN (3.31 vs. 0.020 and 1.004 vs. 0.011 ) and MBR (9.75 vs. 0.131 and 5.87 vs. 0.057 ) but not for MCN $(\overline{\mathrm{x}}=1.03$ and $\overline{\mathrm{x}}=0.362)$ and PBR $(\overline{\mathrm{x}}=1.09$ and $\overline{\mathrm{x}}=0.163 \%$, respectively; $P<0.022)$. The most abundant fungal genera at d 100 were Kazachstania for Saccharomycetaceae; Monascus for Monascaceae; Hannaella for an i.s. Tremellales; and Candida for an i.s. Saccharomycetales. The overall results show that INO reduces overall counts of yeasts and molds (Table 6) but increases their diversity. Most molds will not tolerate low $\mathrm{pH}$ and low oxygen concentrations, nevertheless, yeasts can remain active due to their tolerance to low $\mathrm{pH}$ and their ability to ferment sugars to ethanol, allowing them to survive the ensiling process and initiate aerobic spoilage when the silos are opened (Ávila and Carvalho, 2020). Among these, Saccharomycetales have been reported to dominate over other fungi in oat, triticale, and intercropped silages at d 90, especially genera Kazachtania and Pichia (Duniere et al., 2017). The fungal community in the current study differed from Romero et al. (2018) who reported Debaryomycetaceae, Pichiaceae, and an i.s. Saccharomycetales as the dominant fungal families in whole-crop low moisture corn silages at d 100, with a significant decrease of Pichiaceae and an i.s. Saccharomycetales, and an increase of Debaryomycetaceae in INO-treated silages compared to CON. The differences in fungal communities at d 100 between these studies may have been influenced by the differences in their respective initial fungal communities, and differences between RA of unknown sequences at $d 0$. The effects of yeasts present in silages is dependent on their species and metabolism (Pahlow et al., 2003). Keshri et al., (2018) reported a dominance of Candida genus in $90 \mathrm{~d}$ corn silages, which increased with the application of a homofermentative L. plantarum inoculant compared to the control $(96.5 \%$ vs. $74.1 \% \mathrm{RA})$ and was associated with a decrease in aerobic stability. This may be due to the higher levels of lactic acid, which enhances the growth of lactate-assimilating Candida. Conversely, inoculation with L. buchneri increases the aerobic stability of silages because of the reduced growth of these aerobic spoilage yeasts by the presence of acetic acid (Muck et al., 2018), as observed in this study. 
Table 8. Relative abundance (\%) of fungal families identified from internal transcribed spacer 1 (ITS-1) region sequences extracted from chopped whole-crop corn as a function of hybrid (HYB) and silage additives (ADV) at d $100^{1}$

\begin{tabular}{|c|c|c|c|c|c|c|c|c|c|}
\hline \multirow[b]{2}{*}{ Item } & \multicolumn{4}{|c|}{ Hybrid } & \multirow[b]{2}{*}{ Mean } & \multirow[b]{2}{*}{ SEM } & \multicolumn{3}{|c|}{$P$-value } \\
\hline & MCN & PCN & MBR & PBR & & & HYB & ADV & $\mathrm{HYB} \times \mathrm{ADV}$ \\
\hline Saccharomycetaceae & $53.0^{\mathrm{a}}$ & $47.6^{\mathrm{a}}$ & $9.95^{b}$ & $52.7^{\mathrm{a}}$ & & 10.8 & 0.016 & 0.228 & 0.887 \\
\hline Monascaceae & & & & & & 8.27 & 0.911 & 0.006 & 0.369 \\
\hline $\mathrm{CON}$ & - & - & - & - & $44.7^{\mathrm{A}}$ & & & & \\
\hline INO & - & - & - & - & $12.6^{\mathrm{B}}$ & & & & \\
\hline Incertae sedis Tremellales & & & & & & 2.32 & 0.135 & 0.002 & 0.907 \\
\hline $\mathrm{CON}$ & - & - & - & - & $1.19^{\mathrm{A}}$ & & & & \\
\hline INO & - & - & - & - & $8.0^{\mathrm{B}}$ & & & & \\
\hline Incertae sedis Saccharomycetales & & & & & & 1.72 & 0.290 & $<0.001$ & 0.554 \\
\hline CON & - & - & - & - & $0.250^{\mathrm{B}}$ & & & & \\
\hline INO & - & - & - & - & $6.39^{\mathrm{A}}$ & & & & \\
\hline Unidentified fungi & & & & & & 0.60 & 0.075 & $<0.001$ & 0.485 \\
\hline $\mathrm{CON}$ & - & - & - & - & $0.044^{\mathrm{B}}$ & & & & \\
\hline INO & - & - & - & - & $2.04^{\mathrm{A}}$ & & & & \\
\hline Mucoraceae & & & & & & 1.61 & 0.018 & $<0.001$ & 0.022 \\
\hline CON & 0.036 & $0.020^{\mathrm{B}}$ & $0.131^{\mathrm{B}}$ & 0.032 & & & & & \\
\hline INO & $2.03^{\mathrm{b}}$ & $3.31^{\mathrm{A}, \mathrm{b}}$ & $9.75^{\mathrm{A}, \mathrm{a}}$ & $2.15^{\mathrm{b}}$ & & & & & \\
\hline Unidentified Ascomycota & & & & & 1.65 & 2.75 & 0.349 & 0.197 & 0.350 \\
\hline Unidentified Pleosporales & & & & & & 0.41 & $<0.001$ & $<0.001$ & $<0.001$ \\
\hline $\mathrm{CON}$ & 0.054 & $0.011^{\mathrm{B}}$ & $0.057^{\mathrm{B}}$ & 0.015 & & & & & \\
\hline INO & $0.670^{b}$ & $1.004^{\mathrm{A}, \mathrm{b}}$ & $5.87^{\mathrm{A}, \mathrm{a}}$ & $0.311^{b}$ & & & & & \\
\hline Pichiaceae & & & & & & 0.090 & 0.742 & 0.005 & 0.459 \\
\hline $\mathrm{CON}$ & - & - & - & - & $0.056^{\mathrm{B}}$ & & & & \\
\hline INO & - & - & - & - & $0.305^{\mathrm{A}}$ & & & & \\
\hline
\end{tabular}

${ }^{1} \mathrm{MCN}, \mathrm{PCN}, \mathrm{MBR}$, and PBR corn hybrids are TMF2R737, P2089YHR, F2F817, and P1449XR, respectively. Hybrids MCN and MBR are property of Mycogen Seeds (Indianapolis, IN) and hybrids PCN and PBR are property of Pioneer Hi-Bred International (Johnston, IA). CON, control (water); INO, inoculant (Biotal Buchneri 500; Lallemand Animal Nutrition, Milwaukee, WI) delivering L. buchneri 40788 and P. pentosaceus at 400,000 and $100,000 \mathrm{cfu} / \mathrm{g}$ of fresh corn, respectively.

$\mathrm{A}, \mathrm{B}$ Means with different uppercase superscripts within a column are significantly different $(\mathrm{P} \leq 0.05)$.

${ }^{\mathrm{a}-\mathrm{d} M e a n s}$ with different superscripts within a row are significantly different $(\mathrm{P} \leq 0.05)$.

Relationship between microbial taxonomic profiles and silage quality variables at silo opening

The results of the association analysis between microbiota family's RA and silage quality measures at $d 100$ are presented in Table 9. Only those associations with a $P$-value $\leq 0.01$ are reported. The association analysis was conducted separately for CON and INO samples because these are 2 distinct environments and to allow for the evaluation of the associations between microbiota and silage quality without the overriding the effects of inoculation. We found 17 significant associations for CON and 23 for INO. In CON samples, LAB counts increased at high RA of Lactobacillaceae relative to low and medium RA $(P<0.003)$, and at low RA of Enterobacteriaceae, Xanthomonadaceae, Leuconostocaceae, and Moraxellaceae relative to their medium and high RA at d 100 $(\mathrm{P}<0.004)$. Similarly, the concentration of $\mathrm{NH}_{3}-\mathrm{N}$ (\% of total $\left.\mathrm{N}\right)$ was reduced when the RA of Lactobacillaceae was high compared to its low and medium RA, and at a low RA of Leuconostocaceae relative to its medium and high RA at $d 100(P=0.002)$. Lactic acid concentration was increased when Leuconostocaceae and Moraxellaceae RA at d 100 was high relative to the low category $(P<0.005)$. The most abundant genus for Moraxellaceae was Acinetobacter, a ubiquitous taxa of Gram-negative nonfermenting coccobacilli that is known to have several species of animal and human pathogens and that can be found in fields with previous manure applications or animal pressure (Al Atrouni et al., 2016) and that has been reported in several silage studies (Liu et al.,
2019). In this study, Moraxellaceae RA was correlated with key response variables of CON but its role in silage production is unclear and remains to be elucidated.

For INO samples, LAB counts also increased at a high RA of Lactobacillaceae relative to its low RA $(P<0.007)$ and at low RA of Moraxellaceae relative to its high RA at d $100(P<0.009)$. A high RA of Clostridiaceae increased mold counts $(P=0.004)$ and ethanol concentration $(P=0.01)$, and decreased DM recovery $(P=0.005)$ relative to low $R A$ at $d 100$, which reaffirms the undesirable effects of this bacterial family on silage quality (Kung et al., 2018). High RA of Pichiaceae at d 0 and at d 100 were both correlated with increased lactic acid concentration and decreased the $\mathrm{pH}$ at $\mathrm{d}$ 100 relative to low RA $(P<0.009)$. Moreover, the concentration of WSC increased at high RA of Pichiaceae and Trichosporonaceae relative to low RA at d $100(P<0.007)$. Beneficial effects of Pichia sp. on feed preservation under air-tight conditions have been reported (Druvefors et al., 2005; Petersson et al., 1999) and this yeast family is commonly found in silages due to their lactateassimilating capacity and tolerance to low pH (Ávila and Carvalho, 2020).

\section{Summary and Conclusions}

At low DM concentrations (26.3\% to $31.5 \% \mathrm{DM}$ ), the combination inoculant tested extended severalfold the aerobic stability of the conventional and BMR whole-crop corn hybrids evaluated 
Table 9. Effect of microbiota families relative abundance on quality measures of chopped whole corn at d 100

\begin{tabular}{|c|c|c|c|c|c|}
\hline \multirow[b]{2}{*}{ Item } & \multicolumn{4}{|c|}{ Families relative abundance ${ }^{1}$} & \multirow[b]{2}{*}{ P-valu } \\
\hline & Family and day & Low & Medium & High & \\
\hline \multicolumn{6}{|l|}{ CON samples } \\
\hline Lactic acid bacteria, log cfu/g FW ${ }^{2}$ & Unidentified Dothideomycetes, $0 \mathrm{~d}$ & $0.320^{\mathrm{a}}$ & $0.666^{\mathrm{a}}$ & $-0.655^{b}$ & 0.008 \\
\hline L:A ratio & Unidentified Dothideomycetes, $0 \mathrm{~d}$ & $-0.679^{a}$ & $-0.838^{a}$ & $1.399^{b}$ & 0.001 \\
\hline $\mathrm{L}:$ A ratio & Nectriaceae, $0 \mathrm{~d}$ & $-0.930^{\mathrm{a}}$ & $-0.274^{\mathrm{ab}}$ & $1.227^{\mathrm{b}}$ & 0.006 \\
\hline $\mathrm{NH}_{3}-\mathrm{N}, \%$ of total $\mathrm{N}$ & Leuconostocaceae, $0 \mathrm{~d}$ & $0.003^{\mathrm{a}}$ & $-0.007^{b}$ & $0.005^{\mathrm{a}}$ & 0.005 \\
\hline Yeast, $\log \mathrm{cfu} / \mathrm{g} \mathrm{FW}^{2}$ & Sphingomonadaceae, $0 \mathrm{~d}$ & $0.789^{\mathrm{a}}$ & $-0.589^{b}$ & $-0.200^{\mathrm{ab}}$ & 0.008 \\
\hline Lactic acid bacteria, log cfu/g FW ${ }^{2}$ & Enterobacteriaceae, $100 \mathrm{~d}$ & $0.855^{\mathrm{a}}$ & $-0.372^{b}$ & $-0.540^{\mathrm{b}}$ & 0.004 \\
\hline Lactic acid bacteria, $\log \mathrm{cfu} / \mathrm{g} \mathrm{FW}^{2}$ & Lactobacillaceae, $100 \mathrm{~d}$ & $-0.542^{\mathrm{a}}$ & $-0.377^{\mathrm{a}}$ & $0.862^{\mathrm{b}}$ & 0.003 \\
\hline Lactic acid bacteria, log cfu/g FW ${ }^{2}$ & Leuconostocaceae, $100 \mathrm{~d}$ & $0.884^{a}$ & $0.085^{b}$ & $-1.026^{c}$ & 0.000 \\
\hline Lactic acid bacteria, log cfu/g FW ${ }^{2}$ & Moraxellaceae, $100 \mathrm{~d}$ & $0.946^{\mathrm{a}}$ & $-0.017^{b}$ & $-0.986^{c}$ & 0.000 \\
\hline Lactic acid bacteria, log cfu/g FW ${ }^{2}$ & Unidentified Ascomycota, $100 \mathrm{~d}$ & $0.091^{\mathrm{ab}}$ & $0.628^{a}$ & $-0.717^{b}$ & 0.008 \\
\hline Lactic acid bacteria, log cfu/g FW ${ }^{2}$ & Xanthomonadaceae, $100 \mathrm{~d}$ & $0.876^{a}$ & $-0.077^{b}$ & $-0.856^{b}$ & 0.000 \\
\hline Lactic acid (L), \% of DM & Leuconostocaceae, $100 \mathrm{~d}$ & $-0.934^{\mathrm{a}}$ & $0.182^{\mathrm{ab}}$ & $0.992^{\mathrm{b}}$ & 0.004 \\
\hline Lactic acid (L), \% of DM & Moraxellaceae, $100 \mathrm{~d}$ & $-0.887^{a}$ & $0.090^{\mathrm{ab}}$ & $1.037^{\mathrm{b}}$ & 0.005 \\
\hline $\mathrm{NH}_{3}-\mathrm{N}, \%$ of total $\mathrm{N}$ & Lactobacillaceae, $100 \mathrm{~d}$ & $0.004^{a}$ & $0.006^{\mathrm{a}}$ & $-0.007^{b}$ & 0.001 \\
\hline $\mathrm{NH}_{3}^{3}-\mathrm{N}, \%$ of total $\mathrm{N}$ & Leuconostocaceae, $100 \mathrm{~d}$ & $-0.007^{\mathrm{a}}$ & $0.004^{\mathrm{b}}$ & $0.006^{\mathrm{b}}$ & 0.002 \\
\hline $\mathrm{pH}^{3}$ & Moraxellaceae, $100 \mathrm{~d}$ & $0.046^{a}$ & $-0.010^{b}$ & $-0.040^{\mathrm{b}}$ & 0.002 \\
\hline $\mathrm{NDF}, \%$ of $\mathrm{DM}$ & Moraxellaceae, $100 \mathrm{~d}$ & $-0.331^{a}$ & $1.071^{\mathrm{b}}$ & $-0.969^{\mathrm{a}}$ & 0.003 \\
\hline \multicolumn{6}{|l|}{ INO samples } \\
\hline Acetic acid (A), \% of DM & Brucellaceae, $0 \mathrm{~d}$ & $-0.391^{\mathrm{a}}$ & $1.193^{b}$ & $-0.344^{a}$ & 0.007 \\
\hline Lactic acid (L), \% of DM & Pichiaceae, $0 \mathrm{~d}$ & $-1.084^{a}$ & $-0.030^{\mathrm{ab}}$ & $1.114^{b}$ & 0.009 \\
\hline L:A ratio & Brucellaceae, $0 \mathrm{~d}$ & $0.442^{\mathrm{a}}$ & $-0.879^{b}$ & $0.212^{\mathrm{a}}$ & 0.008 \\
\hline $\mathrm{L}:$ A ratio & Alcaligenaceae, $0 \mathrm{~d}$ & $0.257^{\mathrm{a}}$ & $-0.894^{b}$ & $0.409^{a}$ & 0.007 \\
\hline $\mathrm{L}:(\mathrm{A}+\mathrm{OH})$ ratio $^{3}$ & Brucellaceae, $0 \mathrm{~d}$ & $0.276^{\mathrm{a}}$ & $-0.519^{b}$ & $0.125^{\mathrm{a}}$ & 0.007 \\
\hline $\mathrm{L}:(\mathrm{A}+\mathrm{OH})$ ratio $^{3}$ & Alcaligenaceae, $0 \mathrm{~d}$ & $0.135^{\mathrm{a}}$ & $-0.512^{b}$ & $0.260^{\mathrm{a}}$ & 0.009 \\
\hline $\mathrm{pH}$ & Pichiaceae, $0 \mathrm{~d}$ & $0.070^{\mathrm{a}}$ & $0.001^{\mathrm{ab}}$ & $-0.070^{b}$ & 0.004 \\
\hline $\mathrm{OM}, \%$ of $\mathrm{DM}$ & SUP05, $0 \mathrm{~d}$ & $-0.077^{a}$ & $-0.031^{\mathrm{a}}$ & $0.104^{b}$ & 0.004 \\
\hline $\mathrm{ADF}, \%$ of $\mathrm{DM}$ & Comamonadaceae, $0 \mathrm{~d}$ & $-0.883^{a}$ & $0.608^{b}$ & $0.248^{b}$ & 0.002 \\
\hline DM recovery, \% & Clostridiaceae, $100 \mathrm{~d}$ & $2.063^{\mathrm{a}}$ & $-0.522^{b}$ & $-1.541^{b}$ & 0.005 \\
\hline Molds, log cfu/g FW & Clostridiaceae, $100 \mathrm{~d}$ & $-1.312^{\mathrm{a}}$ & $0.398^{\mathrm{b}}$ & $0.914^{\mathrm{b}}$ & 0.004 \\
\hline Lactic acid bacteria, log cfu/g FW ${ }^{2}$ & Lactobacillaceae, $100 \mathrm{~d}$ & $-0.188^{\mathrm{a}}$ & $-0.008^{\mathrm{ab}}$ & $0.196^{\mathrm{b}}$ & 0.007 \\
\hline Lactic acid bacteria, $\log \mathrm{cfu} / \mathrm{g} \mathrm{FW}^{2}$ & Moraxellaceae, $100 \mathrm{~d}$ & $0.209^{a}$ & $-0.049^{\mathrm{ab}}$ & $-0.160^{b}$ & 0.009 \\
\hline Lactic acid (L), \% of DM & Pichiaceae, $100 \mathrm{~d}$ & $-1.318^{a}$ & $-0.001^{\mathrm{ab}}$ & $1.350^{\mathrm{b}}$ & 0.002 \\
\hline Ethanol, \% of DM & Clostridiaceae, $100 \mathrm{~d}$ & $-0.090^{\mathrm{a}}$ & $-0.058^{\mathrm{a}}$ & $0.148^{\mathrm{b}}$ & 0.010 \\
\hline Ethanol, \% of DM & Phaeosphaeriaceae, $100 \mathrm{~d}$ & $-0.044^{\mathrm{a}}$ & $0.152^{\mathrm{b}}$ & $-0.108^{a}$ & 0.005 \\
\hline $\mathrm{pH}$ & Pichiaceae, $100 \mathrm{~d}$ & $0.078^{\mathrm{a}}$ & $-0.023^{b}$ & $-0.088^{b}$ & 0.000 \\
\hline $\mathrm{pH}$ & Trichosporonaceae, $100 \mathrm{~d}$ & $0.027^{\mathrm{a}}$ & $0.057^{\mathrm{a}}$ & $-0.094^{b}$ & 0.001 \\
\hline WSC, $\%$ of $\mathrm{DM}^{4}$ & Pichiaceae, $100 \mathrm{~d}$ & $-0.157^{a}$ & $0.082^{\mathrm{ab}}$ & $0.206^{\mathrm{b}}$ & 0.007 \\
\hline WSC, $\%$ of $\mathrm{DM}^{4}$ & Trichosporonaceae, $100 \mathrm{~d}$ & $-0.082^{\mathrm{a}}$ & $-0.104^{\mathrm{a}}$ & $0.263^{b}$ & 0.002 \\
\hline $\mathrm{DM}, \%$ & Unidentified Fungi, $100 \mathrm{~d}$ & $0.725^{\mathrm{a}}$ & $-0.169^{\mathrm{ab}}$ & $-0.556^{\mathrm{b}}$ & 0.005 \\
\hline $\mathrm{CP}, \%$ of $\mathrm{DM}$ & Mucoraceae, $100 \mathrm{~d}$ & $0.133^{\mathrm{a}}$ & $0.129^{\mathrm{a}}$ & $-0.321^{b}$ & 0.004 \\
\hline $\mathrm{CP}, \%$ of $\mathrm{DM}$ & Incertae sedis Sporidiobolales, $100 \mathrm{~d}$ & $-0.033^{\mathrm{ab}}$ & $0.278^{\mathrm{a}}$ & $-0.263^{b}$ & 0.007 \\
\hline
\end{tabular}

${ }^{1}$ Microbiota relative abundance was classified into three categories as separated by the 34 th and 67 th percentiles and tested via least squares analysis with pairwise contrasts. Coefficients with different letters within a row are different, $P \leq 0.05$.

${ }^{2} \mathrm{FW}$, fresh corn.

${ }^{3} \mathrm{OH}$, Ethanol plus 1,2-propanediol.

${ }^{4}$ WSC, water soluble carbohydrates.

in laboratory silos by increasing the acetic acid concentration above $3 \%$ of DM at the expense of lactic acid. This in turn decreased the yeast and mold counts after $100 \mathrm{~d}$ of ensiling but also increased fungal OTU richness and evenness across all hybrids relative to untreated hybrids at $d 100$. Our study validates that the inoculant evaluated consistently favors certain fungal taxa, including Mucoraceae. Simultaneously, an increased dominance of Lactobacillaceae at the expense of Enterobacteriaceae, among other undesirable bacteria, was observed in INO-treated silages relative to untreated.
Consequently, INO decreased bacterial taxonomic richness and evenness across all hybrids. All these changes due to inoculation occurred in spite of divergent fungal populations across hybrids at d 0, especially for the BMR hybrids. Also, the high production of acetic acid in this study contributed to the decrease in DM recovery across all INO-treated silages. Unveiled correlations with the metadata involving Pichiaceae, Clostridiaceae, and Moraxellaceae, among others implicate novel players and roles that could help explain variable inoculation effects on silage preservation across the literature. 


\section{Supplementary Data}

Supplementary data are available at Journal of Animal Science online.

\section{Acknowledgments}

Funding contribution was provided by the North Carolina Dairy Producers Association (Raleigh, NC) and the inoculant was donated by Lallemand Animal Nutrition (Milwaukee, WI). We acknowledge the outstanding work of M. Dalman and A. Heitman (NCSU), Carrie Brinton (Official Variety Testing Program at NC State), and the staff from the NCDA Mountain Research Station (Waynesville, NC). This project was also supported by the USDA National Institute of Food and Agriculture Hatch Project number ME0-21917 through the Maine Agricultural and Forest Experiment Station (Publication number 3823).

\section{Conflict of interest statement}

The authors have not stated any conflicts of interest.

\section{References}

Al Atrouni, A., M. L. Joly-Guillou, M. Hamze, and M. Kempf. 2016. Reservoirs of Non-baumannii Acinetobacter Species. Front. Microbiol. 7:49. doi:10.3389/fmicb.2016.00049.

Allen, M. S., J. G. Coors, and G. W. Roth. 2003. Corn silage, silage science and technology. Madison (WI): American Society of Agronomy, Crop Science Society; p 547-608.

Arriola, K. G., S. C. Kim, and A. T. Adesogan. 2011. Effect of applying inoculants with heterolactic or homolactic and heterolactic bacteria on the fermentation and quality of corn silage. J. Dairy Sci. 94(3):1511-1516. doi:10.3168/jds.2010-3807.

Arriola, K. G., S. C. Kim, C. M. Huisden, and A. T. Adesogan. 2012. Stay-green ranking and maturity of corn hybrids: 1. Effects on dry matter yield, nutritional value, fermentation characteristics, and aerobic stability of silage hybrids in Florida. J. Dairy Sci. 95(2):964-974. doi:10.3168/jds.2011-4524.

Ávila, C. L. S., and B. F. Carvalho. 2020. Silage fermentationupdates focusing on the performance of micro-organisms. J. Appl. Microbiol. 128:966-984. doi:10.1111/jam.14450.

Basso, F. C., T. F. Bernardes, A. P. D. T. P. Roth, B. N. Lodo, T. T. Berchielli, and R. A. Reis. 2012. Fermentation and aerobic stability of corn silage inoculated with Lactobacillus buchneri. Rev. Bras. Zootec. 41(7):1789-1794. doi:10.1590/ S1516-35982012000700032.

Bernardi, A., C. J. Härter, A. W. L. Silva, R. A. Reis, and C. H. S. Rabelo. 2019. A meta-analysis examining lactic acid bacteria inoculants for maize silage: Effects on fermentation, aerobic stability, nutritive value and livestock production. Grass Forage Sci. 74(4):596-612. doi:10.1111/gfs.12452.

Blajman, J. E., R. B. Páez, C. G. Vinderola, M. S. Lingua, and M. L. Signorini. 2018. A meta-analysis on the effectiveness of homofermentative and heterofermentative lactic acid bacteria for corn silage. J. Appl. Microbiol. 125(6):1655-1669. doi:10.1111/jam.14084.

Bokulich, N. A., and D. A. Mills. 2013. Improved selection of internal transcribed spacer-specific primers enables quantitative, ultra-high-throughput profiling of fungal communities. Appl. Environ. Microbiol. 79(8):2519-2526. doi:10.1128/aem.03870-12.

Borreani, G., E. Tabacco, R. J. Schmidt, B. J. Holmes, and R. E. Muck. 2018. Silage review: factors affecting dry matter and quality losses in silages. J. Dairy Sci. 101:3952-3979. doi:10.3168/ jds.2017-13837.

Bruice, P. Y. 2004. Organic chemistry. Upper Saddle River (NJ): Pearson/Prentice Hall.
Caporaso, J. G., C. L. Lauber, W. A. Walters, D. Berg-Lyons, C. A. Lozupone, P. J. Turnbaugh, N. Fierer, and R. Knight. 2011. Global patterns of 16S rRNA diversity at a depth of millions of sequences per sample. Proc. Natl. Acad. Sci. 108(Supplement 1):4516-4522. doi:10.1073/pnas.1000080107.

Cole, J. R., Q. Wang, E. Cardenas, J. Fish, B. Chai, R. J. Farris, A. S. KulamSyed-Mohideen, D. M. McGarrell, T. Marsh, G. M. Garrity, and J. M. Tiedje. 2009. The Ribosomal Database Project: improved alignments and new tools for rRNA analysis. Nucleic Acids Res. 37(suppl_1):D141-D145. doi:10.1093/nar/gkn879.

Comino, L., E. Tabacco, F. Righi, A. Revello-Chion, A. Quarantelli, and G. Borreani. 2014. Effects of an inoculant containing a Lactobacillus buchneri that produces ferulate-esterase on fermentation products, aerobic stability, and fibre digestibility of maize silage harvested at different stages of maturity. Anim. Feed Sci. Technol. 198:94-106. doi:10.1016/j. anifeedsci.2014.10.001.

Darby, H. M., and J. G. Lauer. 2002. Harvest date and hybrid influence on corn forage yield, quality, and preservation. Agron. J. 94(3):559-566. doi:10.2134/agronj2002.5590.

Dowd, P. F., D. L. Funnell-Harris, and S. E. Sattler. 2016. Field damage of sorghum (Sorghum bicolor) with reduced lignin levels by naturally occurring insect pests and pathogens. J. Pest Sci. 89(4):885-895. doi:10.1007/s10340-015-0728-1.

Driehuis, F., S. J. W. H. Oude Elferink, and P. G. Van Wikselaar. 2001. Fermentation characteristics and aerobic stability of grass silage inoculated with Lactobacillus buchneri, with or without homofermentative lactic acid bacteria. Grass Forage Sci. 56(4):330-343. doi:10.1046/j.1365-2494.2001.00282.x.

Drouin, P., J. Tremblay, and F. Chaucheyras-Durand. 2019. Dynamic succession of microbiota during ensiling of whole plant corn following inoculation with Lactobacillus buchneri and Lactobacillus hilgardii alone or in combination. Microorganisms 7(12):595.

Druvefors, U. A., V. Passoth, and J. Schnürer. 2005. Nutrient effects on biocontrol of Penicillium roqueforti by Pichia anomala J121 during airtight storage of wheat. Appl. Environ. Microbiol. 71:1865-1869. doi:10.1128/AEM.71.4.1865-1869.2005.

Duniere, L., S. Xu, J. Long, C. Elekwachi, Y. Wang, K. Turkington, R. Forster, and T. A. McAllister. 2017. Bacterial and fungal core microbiomes associated with small grain silages during ensiling and aerobic spoilage. BMC Microbiol. 17:50. doi:10.1186/s12866-017-0947-0.

Filya, I., E. Sucu, and A. Karabulut. 2006. The effect of Lactobacillus buchneri on the fermentation, aerobic stability and ruminal degradability of maize silage. J. Appl. Microbiol. 101:1216-1223. doi:10.1111/j.1365-2672.2006.03038.x.

Fox, J., and S. Weisberg. 2018. An R companion to applied regression. Thousands Oaks, CA: Sage.

Freitas, J. R. D., J. J. Schoenau, S. M. Boyetchko, and S. A. Cyrenne. 2003. Soil microbial populations, community composition, and activity as affected by repeated applications of hog and cattle manure in eastern Saskatchewan. Can. J. Microbiol. 49(9):538-548. doi:10.1139/w03-069 \%M 14608420.

Gerlach, K., F. Roß, K. Weiß, W. Büscher, and K.-H. Südekum. 2013. Changes in maize silage fermentation products during aerobic deterioration and effects on dry matter intake by goats. Agric. Food Sci. 22(1):168-181. doi:10.23986/afsci.6739.

Gharechahi, J., Z. A. Kharazian, S. Sarikhan, G. S. Jouzani, M. Aghdasi, and G. Hosseini Salekdeh. 2017. The dynamics of the bacterial communities developed in maize silage. Microb. Biotechnol. 10:1663-1676. doi:10.1111/1751-7915.12751.

Guan, H., Y. Shuai, Y. Yan, Q. Ran, X. Wang, D. Li, Y. Cai, and X. Zhang. 2020. Microbial community and fermentation dynamics of corn silage prepared with heat-resistant lactic acid bacteria in a hot environment. Microorganisms 8(5):719. doi:10.3390/microorganisms8050719.

Heron, S. J., J. Wilkinson, and C. M. Duffus. 1993. Enterobacteria associated with grass and silages. J. Appl. Bacteriol. 75(1):13-17. doi:10.1111/j.1365-2672.1993.tb03401.x 
Kaewwichian, R., S. Jindamorakot, S. Am-In, M. Sipiczki, and S. Limtong. 2015. Hannaella siamensis sp. nov. and Hannaella phetchabunensis sp. nov., two new anamorphic basidiomycetous yeast species isolated from plants. Int.J. Syst. Evol. Microbiol. 65(Pt 4):1297-1303. doi:10.1099/ijs.0.000101.

Kertz, A. F. 1998. Variability in delivery of nutrients to lactating dairy cows. J. Dairy Sci. 81:3075-3084. doi:10.3168/jds. S0022-0302(98)75872-2.

Keshri, J., Y. Chen, R. Pinto, Y. Kroupitski, Z. G. Weinberg, and S. Sela Saldinger. 2018. Microbiome dynamics during ensiling of corn with and without Lactobacillus plantarum inoculant. Appl. Microbiol. Biotechnol. 102:4025-4037. doi:10.1007/ s00253-018-8903-y.

Kong, X., Z. Han, X. Tai, D. Jin, S. Ai, X. Zheng, and Z. Bai. 2020. Maize (Zea mays L. Sp.) varieties significantly influence bacterial and fungal community in bulk soil, rhizosphere soil and phyllosphere. FEMS Microbiol. Ecol. 96(3):1-11. doi:10.1093/ femsec/fiaa020.

Kung, Jr, L., J. M. Lim, D. J. Hudson, J. M. Smith, and R. D. Joerger. 2015. Chemical composition and nutritive value of corn silage harvested in the northeastern United States after Tropical Storm Irene. J. Dairy Sci. 98(3):2055-2062. doi:10.3168/jds.2014-8621.

Kung, L., Jr, R. D. Shaver, R. J. Grant, and R. J. Schmidt. 2018. Silage review: interpretation of chemical, microbial, and organoleptic components of silages. J. Dairy Sci. 101:40204033. doi:10.3168/jds.2017-13909.

Lane, B., S. Sharma, C. Niu, A. W. Maina, J. M. Wagacha, B. H. Bluhm, and C. P. Woloshuk. 2018. Changes in the fungal microbiome of maize during hermetic storage in the United States and Kenya. Front. Microbiol. 9:2336. doi:10.3389/ fmicb.2018.02336.

Lenth, R. V. 2016. Using lsmeans. J. Stat. Softw. 69:1-33. doi:10.18637/jss.v069.i01.

Lewis, A. L., W. J. Cox, and J. H. Cherney. 2004. Hybrid, maturity, and cutting height interactions on corn forage yield and quality. Agron. J. 96(1):267-274. doi:10.2134/agronj2004.2670.

Limtong, S., and R. Nasanit. 2017. Phylloplane yeasts in tropical climates. In: Buzzini, P., M.-A. Lachance, and A. Yurkov, editors, Yeasts in natural ecosystems: diversity. Cham: Springer International Publishing; $p$ 199-223.

Liu, B., H. Huan, H. Gu, N. Xu, Q. Shen, and C. Ding. 2019. Dynamics of a microbial community during ensiling and upon aerobic exposure in lactic acid bacteria inoculationtreated and untreated barley silages. Bioresour. Technol. 273:212-219. doi:10.1016/j.biortech.2018.10.041.

Lozupone, C., and R. Knight. 2005. UniFrac: a new phylogenetic method for comparing microbial communities. Appl. Environ. Microbiol. 71:8228-8235. doi:10.1128/AEM.71.12.82288235.2005.

Martinez-Fernández, A., A. B. S. Cabezuelo, M. B. de la Roza Delgado, M. G. Arrojo, and A. A. Gutiérrez. 2013. Modelling a quantitative ensilability index adapted to forages from wet temperate areas. Span. J. Agric. Res. 2:455-462. doi:10.5424/ sjar/2013112-3219.

Mataragas, M., J. Metaxopoulos, and E. H. Drosinos. 2002. Characterization of two bacteriocins produced by Leuconostoc mesenteroides L124 and Lactobacillus curvatus L442, isolated from dry fermented sausages. World J. Microbiol. Biotechnol. 18(9):847-856. doi:10.1023/A:1021239008582.

May, L. A., B. Smiley, and M. G. Schmidt. 2001. Comparative denaturing gradient gel electrophoresis analysis of fungal communities associated with whole plant corn silage. Can. J. Microbiol. 47:829-841. doi:10.1139/w01-086.

McEniry, J., P. O’Kiely, N. J. Clipson, P. D. Forristal, and E. M. Doyle. 2010. Assessing the impact of various ensilage factors on the fermentation of grass silage using conventional culture and bacterial community analysis techniques. J. Appl. Microbiol. 108:1584-1593. doi:10.1111/j.1365-2672.2009.04557.x.

Miron, J., E. Zuckerman, G. Adin, R. Solomon, E. Shoshani, M. Nikbachat, E. Yosef, A. Zenou, Z. G. Weinberg, Y. Chen,
I. Halachmi, and D. Ben-Ghedalia. 2007. Comparison of two forage sorghum varieties with corn and the effect of feeding their silages on eating behavior and lactation performance of dairy cows. Anim. Feed Sci. Technol. 139(1):23-39. doi:10.1016/j. anifeedsci.2007.01.011.

Muck, R. E., E. M. G. Nadeau, T. A. McAllister, F. E. ContrerasGovea, M. C. Santos, and L. Kung, Jr. 2018. Silage review: recent advances and future uses of silage additives. J. Dairy Sci. 101:3980-4000. doi:10.3168/jds.2017-13839.

Ni, K., T. T. Minh, T. T. Tu, T. Tsuruta, H. Pang, and N. Nishino. 2017. Comparative microbiota assessment of wilted Italian ryegrass, whole crop corn, and wilted alfalfa silage using denaturing gradient gel electrophoresis and next-generation sequencing. Appl. Microbiol. Biotechnol. 101:1385-1394. doi:10.1007/s00253-016-7900-2.

Oude Elferink, S. J., J. Krooneman, J. C. Gottschal, S. F. Spoelstra, F. Faber, and F. Driehuis. 2001. Anaerobic conversion of lactic acid to acetic acid and 1,2-propanediol by Lactobacillus buchneri. Appl. Environ. Microbiol. 67:125-132. doi:10.1128/ AEM.67.1.125-132.2001.

Pahlow, G., R. E. Muck, F. Driehuis, S. J. W. H. Oude Elferink, and S. F. Spoelstra. 2003. Microbiology of Ensiling. In: Buxton, D. R., R. E. Muck, and J. H. Harrison, editor. Silage science and technology. Madison (WI): Agronomy Monographs: ASA, CSSA and SSSA.

Petersson, S., N. Jonsson, and J. Schnürer. 1999. Pichia anomala as a biocontrol agent during storage of high-moisture feed grain under airtight conditions. Postharvest Biol. Technol. 15(2):175-184. doi:10.1016/S0925-5214(98)00081-7.

Pitt, R. E., and R. Y. Leibensperger. 1987. The effectiveness of silage inoculants: a systems approach. Agric. Syst. 25(1):27-49. doi:10.1016/0308-521X(87)90097-7.

Queiroz, O. C. M., K. G. Arriola, J. L. P. Daniel, and A. T. Adesogan. 2013. Effects of 8 chemical and bacterial additives on the quality of corn silage. J. Dairy Sci. 96(9):5836-5843. doi:10.3168/ jds.2013-6691.

Queiroz, O. C. M., I. M. Ogunade, Z. Weinberg, and A. T. Adesogan. 2018. Silage review: foodborne pathogens in silage and their mitigation by silage additives. J. Dairy Sci. 101:4132-4142. doi:10.3168/jds.2017-13901.

Romero, J. J., Y. Joo, J. Park, F. Tiezzi, E. Gutierrez-Rodriguez, and M. S. Castillo. 2018. Bacterial and fungal communities, fermentation, and aerobic stability of conventional hybrids and brown midrib hybrids ensiled at low moisture with or without a homo- and heterofermentative inoculant. J. Dairy Sci. 101:3057-3076. doi:10.3168/jds.2017-13754.

Rosenzweig, C., A. Iglesias, X. Yang, P. R. Epstein, and E. Chivian. 2001. Climate change and extreme weather events; implications for food production, plant diseases, and pests. Glob. Change Human Heal. 2(2):90-104. doi:10.1023/A:1015086831467.

Rotz, C. A., S. A. Ford, and D. R. Buckmaster. 2003. Silages in farming systems. In: D. R. Buxton, R. E. Muck and J. H. Harrison, editors, Silage science and technology No. 42. ASA, CSS, SSA, Madison, WI. p. 505-546.

SAS Institute. 2019. SAS/SHARE 9.4 User's Guide. Cary, NC: SAS Institute Inc.

Sniffen, C. J., R. W. Beverly, C. S. Mooney, M. B. Roe, A. L. Skidmore, and J. R. Black. 1993. Nutrient requirements versus supply in the dairy cow: strategies to account for variability. J. Dairy Sci. 76:3160-3178. doi:10.3168/jds.S0022-0302(93)77655-9.

Tylutki, T., and D. Fox. 2000. Managing the dairy feeding system to minimize manure nutrients. Proceedings from Managing Nutrients and Pathogens from Animal Agriculture. March 28-30.

Wagner, M. R., J. H. Roberts, P. Balint-Kurti, and J. B. Holland. 2020. Heterosis of leaf and rhizosphere microbiomes in field-grown maize. New Phytol. 228:1055-1069. doi:10.1111/nph.16730.

Wang, J., S. K. Vanga, R. Saxena, V. Orsat, and V. Raghavan. 2018. Effect of climate change on the yield of cereal crops: a review. Climate 6(2):41. doi:10.3390/cli6020041. 
Wilde, F. D., L. J. Britton, C. V. Miller, and D. W. Kolpin. 2000. Effects of animal feeding operations on water resources and the environment. Reston, VA: US Geological Survey.

Wilkinson, J. M., and D. R. Davies. 2013. The aerobic stability of silage: key findings and recent developments. Grass Forage Sci. 68(1):1-19. doi:10.1111/j.1365-2494.2012.00891.x.

Windle, M. C., N. Walker, and L. Kung, Jr. 2014. Effects of an exogenous protease on the fermentation and nutritive value of corn silage harvested at different dry matter contents and ensiled for various lengths of time. J. Dairy Sci. 97:3053-3060. doi:10.3168/jds.2013-7586.
Xu, D., W. Ding, W. Ke, F. Li, P. Zhang, and X. Guo. 2019. Modulation of metabolome and bacterial community in whole crop corn silage by inoculating homofermentative Lactobacillus plantarum and heterofermentative Lactobacillus buchneri. Front. Microbiol. 9(3299):1-14. doi:10.3389/fmicb.2018.03299.

Yin, Z., C. Yuan, Y. Du, P. Yang, C. Qian, Y. Wei, S. Zhang, D. Huang, and B. Liu. 2019. Comparative genomic analysis of the Hafnia genus reveals an explicit evolutionary relationship between the species alvei and paralvei and provides insights into pathogenicity. BMC Genomics 20:768. doi:10.1186/ s12864-019-6123-1. 